\title{
Conditions of spatiotemporal variability of the thickness of the ice cover on lakes in the Tatra Mountains
}

\author{
Maksymilian SOLARSKI* iDhttps://orcid.org/oooo-0003-1939-6992; Ne-mail: maxsolarski@poczta.fm \\ Mirosław SZUMNY iD https://orcid.org/oooo-0oo2-4914-9899; e-mail: mszumny@wp.pl \\ ${ }^{*}$ Corresponding author \\ Faculty of Natural Sciences, University of Silesia, 41-20o Sosnowiec, ul. Będzińska 6o, Poland
}

Citation: Solarski M, Szumny M (2020) Conditions of spatiotemporal variability of the thickness of the ice cover on lakes in the Tatra Mountains. Journal of Mountain Science 17(10). https://doi.org/10.1007/s11629-019-5907-8

(C) The Author(s) 2020.

\begin{abstract}
This research aimed to identify the impact of local climatic and topographic conditions on the formation and development of the ice cover in highmountain lakes and the representativeness assessment of periodic point measurements of the ice cover thickness by taking into consideration the role of the avalanches on the icing of the lakes. Field works included measurement of the ice and snow cover thickness of seven lakes situated in the Tatra Mountains (UNESCO biosphere reserve) at the beginning and the end of the 2017/2018 winter season. In addition, morphometric, topographic and daily meteorological data of lakes from local IMGW (Polish Institute of Meteorology and Water Management) stations and satellite images were used. The obtained results enabled us to quantify the impact of the winter eolian snow accumulation on the variation in ice thickness. This variation was ranging from several centimetres up to about 2 meters and had a tendency to increase during the winter season. The thickest ice covers occurred in the most shaded places in the direct vicinity of rock walls. The obtained results confirm a dominating role of the snow cover in the variation of the ice thickness within individual lakes.
\end{abstract}

Keywords: Mountain lakes; Ice cover; Tatra Mountains; Climate change; Ice phenology

Received: 12-Dec-2019

Revised: 26-May-2020

Accepted: 16-Jul-2020

\section{Introduction}

In recent years, there has been a steady increase in research on the ice phenology of lakes and reservoirs in the temperate climatic zone (Magnuson et al. 2000; Solarski et al. 2011; Choiński et al. 2015a; Ariano and Brown 2019; Lopez et al. 2019; Sharma et al. 2019). The studies mainly focused on linking ice regimen patterns with contemporary climate change (Magnuson et al. 2000; Duguay et al. 2003; Marszelewski and Skowron 2006; Salonen et al. 2009; Brown and Duguay 2010; Karetnikov and Naumenko 2011; Pociask-Karteczka and Choiński 2012; Choiński et al. 2015a; Leppäranta 2015; Wrzesiński et al. 2016; Hewitt et al. 2018; Likens 2019; Lopez et al. 2019). The occurrence of ice, and especially of ice cover, has been demonstrated to have a number of impacts on limnic processes, such as: the dynamics of the water mass and its thermal and oxygen conditions (Gao and Stefan 1999; Leppäranta et al. 2003; Šporka et al. 2006; Granados et al. 2020), the available light (Prowse and Stephenson 1986; Leppäranta et al. 2003; Kiili et al. 2009; Lei et al. 2011), gas concentrations (Prowse and Stephenson 1986; Terzhevik et al. 2009; Terzhevik et al. 2010), and chemical and biochemical processes (Shuter et al. 2012). Lake ice in general and that on large lakes in particular is a factor in the development of littoral geomorphology and plant and wildlife 
species (Bryan and Marcus 1972; Cox 1984). Indeed, ice and its cover may be a significant factor in the development of lacustrine biotopes and biocenoses (Greenbank 1945; Fang and Stefan 1998; McCord et al. 2000; Shuter et al. 2012; Santibáñez et al. 2019; Wüest et al. 2019). Ice phenology and changes to the lake ice regimen also influence local communities living near lakes throughout the temperate zone (Knoll et al. 2019). The overwhelming majority of available studies focus on low-altitude lakes, primarily in lowlands and uplands (Solarski et. al. 2011; Choiński et. al. 2015a). Much less is available with regards to the patterns of development of ice cover and the ice phenology of mountain and high-mountain lakes (Livingstone 1997; Ohlendorf et al. 2000). This is primarily explained by their combination of remoteness and difficult access that makes the collection of data physically challenging and, in avalanche-prone areas, also risky.

The issue of the spatial variability of ice thickness has been widely addressed in the limnological literature in relation to lowland lakes and anthropogenic water bodies located in different parts of the world (Andrews 1962; Adams and Shaw 1967; Sokolnikov 1969 after Choiński 2007a; Adams and Roulet 1980, 1984; Adams 1981, 1982, 1984; Bengtsson 1986; Choiński et al. 2006; Choiński 2007a, 2007b; Jankowski et al. 2009; Machowski and Ruman 2009; Choiński et al. 2010; Piątek et al. 2010; Solarski and Pradela 2010; Rzętała and Solarski 2011; Solarski et al. 2011; Choiński and Ptak 2012, 2013; Choiński et al. 2013). However, few studies have addressed the problem of surface variation in the thickness of ice on mountain lakes (Choiński 2007a, 2007b, 2016; Choiński et al. 2013). Existing research on the surface variability of the thickness of ice on lowland lakes and highland water reservoirs demonstrates that the surface variability of the thickness of the ice cover on lakes is influenced by several factors, with the compaction of the ice cover by the layer of snow accumulated on it in winter and the build-up of white snow on top of the ice cover coming to the fore (Bengtsson 1986; Solarski et al. 2011). In the initial stages of lake ice formation, the variation in ice thickness is small (several centimetres) which increases considerably in snowy winters (Solarski et al. 2011). Research by Adams and Roulet $(1980,1984)$ shows that the redistribution of the snow layer by wind gives rise to local differences in the thickness of white and crystalline ice and the thickness of the snow layer accumulated thereon. The researchers have found that a thicker layer of snow (brought in by wind) accumulates near the shores, forming snowdrifts (Adams and Roulet 1980, 1984). Initially, this hinders the formation of crystalline ice due to the insulating properties of the snow, but this then triggers ice cover compaction processes, which lead to the formation of snow ice (Leppäranta 1983, 2009, 2015). Consequently, researchers have found a thicker layer of crystalline ice in the central areas of the lake, and a greater proportion of snow ice near the shores (Adams and Roulet 1980, 1984).

The history of measurements of the winter water temperature and ice thickness on the lakes included in the study dates back to 1804 when the renowned Polish scientific pioneer Stanisław Staszic explored the Morskie Oko lake (Borucki 2005; Kiełkowski 2018). It was not until 1963, however, that measurements and observations of ice phenomena on this particular lake took on a more regular format (Pawłowski 2018). Additionally, nearly a decade's worth of measurements is also available from Wielki Staw Polski (1971-1979) (Choiński 2017). The earliest information about the thickness of the ice cover on the Tatra lakes and its layered structure appeared in the late $19^{\text {th }}$ century (Wierzejski 1881; Birkenmajer 1901) (Table 1). The information was confirmed by Lityński (1914, 1917), who observed and described the layered structure of lake ice and found that the thickness of the lower layer is inversely proportional to the thickness of the two upper layers. Following this, Olszewski provided information on the formation of layered lake ice (Olszewski 1948a, 1948b, 1949a, 1949b, 1950, 1955), confirming Lityński's earlier observations $(1914,1917)$ (Table 1). Ice of considerable thickness (often in excess of 1 metre) develops as a result of the accumulation of layers of snow on the original ice, which are then saturated with water flowing out through crevices in the snow-loaded ice cover. At very low temperatures, the layer of wet snow freezes. The process repeats many times and leads to the build-up of several layers of ice separated by layers of wet, partly frozen snow or slush. Based on long-term research into the maximum thickness of the Morskie Oko ice cover (Choiński et al. 2006; 
Choiński 2010; Choiński et al. 2010, 2013, 2014, 2015b), a declining trend in the annual maximum thicknesses of the ice has been identified. Researchers have also found a relationship between the thickness of the ice cover and the

Table 1 Examples of the thickness of ice on lakes in the Tatra Mountains.

\begin{tabular}{|c|c|c|c|}
\hline Lake name & $\begin{array}{l}\text { Max. ice } \\
\text { thickness } \\
\text { (cm) }\end{array}$ & Date & $\begin{array}{l}\text { Measurement taken } \\
\text { by }\end{array}$ \\
\hline $\begin{array}{l}\text { Zadni Staw } \\
\text { Polski }\end{array}$ & $\begin{array}{l}130 \\
175 \\
260 \\
267\end{array}$ & $\begin{array}{l}18-26.05 .1932 \\
24.03 .1938 \\
15.05 .1938 \\
22.04 .2018\end{array}$ & $\begin{array}{l}\text { Szaflarski 1936a,b } \\
\text { Olszewski 1948a } \\
\text { Olszewski 1948b } \\
\text { Solarski and Szumny }\end{array}$ \\
\hline $\begin{array}{l}\text { Czarny Staw } \\
\text { Polski }\end{array}$ & $\begin{array}{l}140 \\
170 \\
190\end{array}$ & $\begin{array}{l}25.03 .1938 \\
14.04 .1938 \\
14.05 .1938\end{array}$ & $\begin{array}{l}\text { Olszewski 1948a } \\
\text { Olszewski 1948b } \\
\text { Olszewski 1948b }\end{array}$ \\
\hline $\begin{array}{l}\text { Przedni Staw } \\
\text { Polski }\end{array}$ & $\begin{array}{l}115 \\
155 \\
220\end{array}$ & $\begin{array}{l}26.03 .1938 \\
11.05 .1938 \\
20.03 .2018\end{array}$ & $\begin{array}{l}\text { Olszewski 1948a } \\
\text { Olszewski 1948b } \\
\text { Solarski and Szumny }\end{array}$ \\
\hline $\begin{array}{l}\text { Wielki Staw } \\
\text { Polski }\end{array}$ & $\begin{array}{l}110 \\
135 \\
165 \\
97 \\
100 \\
105\end{array}$ & $\begin{array}{l}27.03 .1938 \\
28.03 .1938 \\
29.03 .1938 \\
1978 \\
1979 \\
20.03 .2018\end{array}$ & $\begin{array}{l}\text { Olszewski 1948a } \\
\text { Olszewski 1948a } \\
\text { Olszewski 1948b } \\
\text { Choiński 2017 } \\
\text { Choiński 2017 } \\
\text { Solarski and Szumny }\end{array}$ \\
\hline $\begin{array}{l}\text { Czarny Staw } \\
\text { Gąsienicowy }\end{array}$ & $\begin{array}{l}\approx 200 \\
100 \\
40-60 \\
10 \\
25 \\
40 \\
60 \\
110 \\
85 \\
350 \\
110\end{array}$ & $\begin{array}{l}1892 / 1893 \\
1911 \\
1911 \\
12.11 .1936 \\
11.12 .1937 \\
15.12 .1937 \\
09.03 .1938 \\
28.04 .1938 \\
18.05 .1938 \\
1937 / 1938 \\
11.02 .2018\end{array}$ & $\begin{array}{l}\text { Birkenmajer } 1901 \\
\text { Lityński } 1917 \\
\text { Lityński } 1917 \\
\text { Olszewski 1948a } \\
\text { Olszewski 1948b } \\
\text { Olszewski 1948a } \\
\text { Olszewski 1948b } \\
\text { Olszewski 1948a } \\
\text { Olszewski 1948b } \\
\text { Olszewski 1948a } \\
\text { Solarski and Szumny }\end{array}$ \\
\hline $\begin{array}{l}\text { Czarny Staw } \\
\text { pod Rysami }\end{array}$ & $\begin{array}{l}40-60 \\
120 \\
90 \\
77^{*} \\
52-95 \\
106\end{array}$ & \begin{tabular}{l|}
03.05 .1911 \\
15.03 .1938 \\
06.05 .1938 \\
24.03 .2010 \\
18.02 .2015 \\
08.04 .2018
\end{tabular} & $\begin{array}{l}\text { Lityński } 1917 \\
\text { Olszewski } 1948 \mathrm{a} \\
\text { Olszewski } 1948 \mathrm{~b} \\
\text { Choiński } 2016 \\
\text { Choiński } 2016 \\
\text { Solarski and Szumny }\end{array}$ \\
\hline Morskie Oko & $\begin{array}{l}80 \\
115-120 \\
80 \\
75 \\
150 \\
100 \text { centre } \\
100 \text { SW } \\
100 \\
130 \\
72^{*} \\
84 \\
74 \\
80 \\
70-100 \\
34-60 \\
85\end{array}$ & $\begin{array}{l}28.02 .1891 \\
25.03 .1891 \\
\text { 01.03.1892 } \\
12,18.01 .1893 \\
12.04 .1893 \\
17.03 .1938 \\
17.03 .1938 \\
05.05 .1938 \\
08.05 .1939 \\
1971-1980 \\
1978 \\
1979 \\
04.03 .1994 \\
11.04 .2007 \\
18.02 .2015 \\
31.03 .2018\end{array}$ & $\begin{array}{l}\text { Birkenmajer } 1901 \\
\text { Birkenmajer } 1901 \\
\text { Świerz 1893 } \\
\text { Birkenmajer } 1901 \\
\text { Świerz 1894 } \\
\text { Olszewski 1948a } \\
\text { Olszewski 1948b } \\
\text { Olszewski 1948a } \\
\text { Szaflarski 1936a,b } \\
\text { Choiński 2017 } \\
\text { Choiński 2017 } \\
\text { Choiński 2017 } \\
\text { Mościcki 1996 } \\
\text { Choiński et al. } 2013 \\
\text { Choiński 2016 } \\
\text { IMGW data 2018 }\end{array}$ \\
\hline
\end{tabular}

Note: ${ }^{*}$ means long-term average. depth of the lake at individual locations and the reach of the shadow cast by the southern faces of the postglacial cirque (Choiński et al. 2006; Choiński 2007a, b). The high variability in the thickness of the ice cover in the Tatras has mainly been attributed to internal factors: circulation of the waters under the ice, the supply of the basin with groundwater, and the release of heat from bottom sediments with the shading of some areas of the lake basin by mountain peaks identified as the only external factor (Choiński 2007a, 2007b; Choiński et al. 2013). This means that research has disregarded the factor that seems crucial, namely non-uniform growth of white ice from the top.

The Tatra lakes begin to freeze over near the shores, where, according to some researchers, ice reaches the greatest thickness (Birkenmajer 1901; Pacl and Wit-Jóźwik 1974; Łajczak 1980, 1982). By contrast, the ice melts the fastest in the central part of the lake, where it is thinnest (Birkenmajer 1901; Pacl and Wit-Jóźwik 1974; Łajczak 1980, 1982; Choiński et al. 2014). According to some authors, these dependencies affect the manner and rate of formation and disappearance of the ice cover on the lake (Szaflarski 1948; Łajczak 1980, 1982; Choiński 2007a, 2007b; Pociask-Karteczka and Choiński 2012, Choiński et al. 2013, Pociask-Karteczka et al. 2014; Choiński et al. 2014) (Table 1).

The objective of this research is to determine the thickness of the snow and ice covers, their spatial and temporal variability and the factors driving this variability on the seven Tatra lakes selected for the study (Figure 1; Table 2). In this way the authors expect to elucidate the following questions:

1) What is the impact of the local topoclimatic and geomorphological conditions on the ice phenomena on the largest lakes in the Polish Tatra Mountains?

2) How useful are ice thickness measurements taken in a single spot for general research on the influence of the climate on lake ice? 


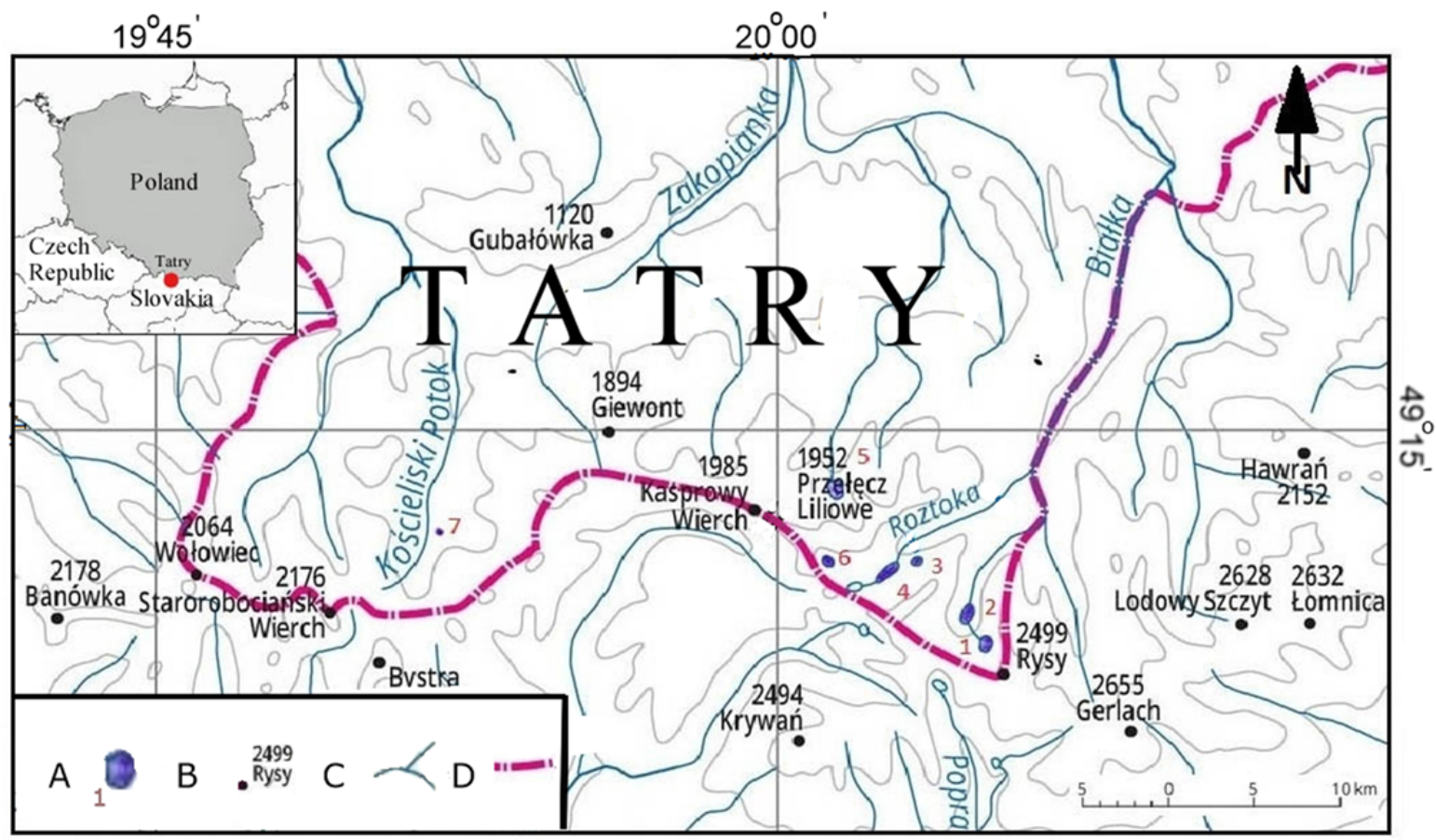

Note: A - Studied lakes: 1 - Czarny Staw Pod Rysami, 2 - Morskie Oko, 3 - Przedni Staw Polski, 4 - Wielki Staw Polski, 5 Czarny Staw Gąsienicowy, 6 - Zadni Staw Polski, 7 - Smreczyński Staw; B - peaks and their heights, C - rivers, D - borders.

Figure 1 Location of the seven studied lakes (Source: https://Epodręczniki.pl).

Table 2 Selected elements of the morphometry of the lakes examined (Source: Gregor and Pacl 2005; IMGW 2007)

\begin{tabular}{|c|c|c|c|c|c|c|c|}
\hline Lake name & $\begin{array}{l}\text { Altitude } \\
\text { (m a.s.l.) }\end{array}$ & $\begin{array}{l}\text { Area } \\
\text { (ha) }\end{array}$ & $\begin{array}{l}\text { Volume } \\
\left(\mathrm{m}^{3}\right)\end{array}$ & $\begin{array}{l}\text { Average } \\
\text { depth } \\
\text { (m) }\end{array}$ & $\begin{array}{l}\text { Max. } \\
\text { depth } \\
(\mathrm{m})\end{array}$ & $\begin{array}{l}\text { Potential } \\
\text { insolation } \\
(\mathrm{kWh})\end{array}$ & Lake location characteristics \\
\hline $\begin{array}{l}\text { Czarny Staw } \\
\text { pod Rysami }\end{array}$ & 1580 & 20.59 & 7761700 & 37.61 & 76.4 & 66222.48 & $\begin{array}{l}\text { Tarn lake lying in a deep, shaded } \\
\text { cirque on the northern side of the Tatra } \\
\text { Mountains. }\end{array}$ \\
\hline Morskie Oko & 1393 & 32.92 & 9904300 & 29.7 & 51.8 & 78179.96 & $\begin{array}{l}\text { Tarn and moraine-dammed lake } \\
\text { located in the upper zone of the spruce } \\
\text { forest. }\end{array}$ \\
\hline $\begin{array}{l}\text { Przedni Staw } \\
\text { Polski }\end{array}$ & 1668 & 7.79 & 1130000 & 14.68 & 34.6 & 90846.32 & $\begin{array}{l}\text { Tarn lake lying above the upper forest } \\
\text { line. }\end{array}$ \\
\hline $\begin{array}{l}\text { Wielki Staw } \\
\text { Polski }\end{array}$ & 1665 & 34.45 & 12967000 & 37.98 & 80.3 & 96736.41 & $\begin{array}{l}\text { The largest lake in the Tatras in terms } \\
\text { of area, volume and depth, lying above } \\
\text { the upper forest line. }\end{array}$ \\
\hline $\begin{array}{l}\text { Zadni Staw } \\
\text { Polski }\end{array}$ & 1890 & 7.1 & 918400 & 14.19 & 31.6 & 71193.88 & $\begin{array}{l}\text { Tarn lake located within the zone of } \\
\text { moderately cold climate and assigned } \\
\text { to the group of frozen ponds in the } \\
\text { classification of Szaflarski (1932). }\end{array}$ \\
\hline $\begin{array}{l}\text { Czarny Staw } \\
\text { Gąsienicowy }\end{array}$ & 1620 & 12.66 & 3798000 & 21.0 & 51.0 & 87286.59 & $\begin{array}{l}\text { Tarn lake lying above the upper forest } \\
\text { line, in the shadow of the northern face } \\
\text { of Kościelec. }\end{array}$ \\
\hline $\begin{array}{l}\text { Smreczyński } \\
\text { Staw }\end{array}$ & 1226 & 0.75 & 13540 & 1.8 & $5 \cdot 3$ & 89359.42 & $\begin{array}{l}\text { Moraine-dammed lake situated in a } \\
\text { spruce forest, heavily shaded, with } \\
\text { poor wind activity. }\end{array}$ \\
\hline
\end{tabular}

\section{Study Area}

The Tatra Mountains are the highest ice-free mountain range of the Carpathians, located in the central part of Europe $\left(49^{\circ} 10^{\prime} \mathrm{N}, 20^{\circ} 10^{\prime} \mathrm{E}\right)$. Their area is about $790 \mathrm{~km}^{2}$ (Balon et al. 2015), about 22\% of which lies in Poland, and the rest in Slovakia (Figure 1). The present-day climate of the Tatras is Alpine, with a transitional character between 
Table 3 Field works on the study lakes in the 2017/2018 winter season

\begin{tabular}{|l|l|l|l|l|}
\hline Lake name & $\begin{array}{l}\text { Measurement date } \\
\text { (Start of the season) }\end{array}$ & $\begin{array}{l}\text { Number of drill } \\
\text { holes }\end{array}$ & $\begin{array}{l}\text { Measurement date } \\
\text { (End of the season) }\end{array}$ & $\begin{array}{l}\text { Number of drill } \\
\text { holes }\end{array}$ \\
\hline Czarny Staw pod Rysami & 10 February 2018 & 18 & 8 April 2018 & 12 \\
\hline Morskie Oko & 16 December 2017 & 27 & 8 April 2018 & 26 \\
\hline Przedni Staw Polski & 18 December 2017 & 12 & 20 March 2018 & 12 \\
\hline Wielki Staw Polski & 12 January 2018 & 18 & 20 March 2018 & 19 \\
\hline Zadni Staw Polski & 19 December 2017 & 13 & 22 April 2018 & 13 \\
\hline Czarny Staw Gąsienicowy & 11 February 2018 & 18 & 15 April 2018 & 22 \\
\hline Smreczyński Staw & 17 December 2017 & 11 & No data & No data \\
\hline
\end{tabular}

maritime and continental. This is attributable to the geographical location, land relief and altitude (Hess 1965). The mean annual air temperature (MAAT) decreases with altitude and is $6^{\circ} \mathrm{C}$ in the northern foreland (approx. $850 \mathrm{~m}$ a.s.l.) and $<-2^{\circ} \mathrm{C}$ on the highest peaks (Eupikasza and Szypuła 2019). At the turn of the 2oth century, an increase in air temperature was observed in the Tatra Mountains, mainly in winter, with a simultaneous decrease in annual snowfall totals (Żmudzka 2011; Gądek 2014). The maximum thickness and durability of the snow covers (Falarz 2002) and ice of lakes (PociaskKarteczka and Choiński 2012) also decreased.

The ice on the Tatra lakes usually lasts from 6 to 10 months. Overall, there are 262 lakes in the Tatras (Kopáček et al. 2004), most of which are located in the High Tatras (81\%). All the lakes in question are of postglacial origin and most are located above the upper line of the spruce forest, with the exception of Smreczyński Staw (1226 m a.s.l.), which lies within the forest zone in the Western Tatras. In terms of area and volume, the Tatra lakes selected for study are also very deep, except for Smreczyński Staw (Table 2). All the lakes examined lie on the northern slope of the Tatra Mountains and are shaded for a large part of the year (Radwańska-Paryska and Paryski 1995) (Figure 1). The morphometric features and location of the study lakes translate into differences in the heating conditions of the lake waters and in the water capacity of the catchment (Łajczak 1980). However, despite the large variations in the altitude at which they lie (from 1220 to $1890 \mathrm{~m}$ a.s.l.), the morphometry of the lake basin, the size and exposure of the topographic catchment, and the screening of the horizon, the lakes have many common features (Table 2) (Eajczak 1996). The total volume of all the lakes in the Tatras is $53 \times 10^{6}$ $\mathrm{m}^{3}$, of which $42 \times 10^{6} \mathrm{~m}^{3}$ lie on the northern slope (Lajczak 1996). The volume of the lakes examined in this study is $39.32 \times 10^{6} \mathrm{~m}^{3}$, which is $74.19 \%$ of all lakes in the Tatras (93.37\% of the lakes located on the northern slope of the mountains).

\section{Methods}

The observation of changes in the thickness of the snow-ice cover on the selected lakes in the winter season 2017/2018 was carried out from the time when a solid and continuous ice sheet formed on the lake (December) until the early phase of its disappearance (April). The thickness of the ice cover was measured at several to several dozen points distributed evenly on the lake's surface (Table 3). The positioning of the points was determined by means of a portable Garmin Montana 600 GPS receiver with an accuracy of 1-2 $\mathrm{m}$. Drill holes at the points were made with an 8" MORA ICE Pro 120 ice drill. The total thickness of the ice cover (as well as of its individual layers) was determined using a measure with an accuracy of $0.5 \mathrm{~cm}$, which was also used to measure the thickness of the snow cover. The results obtained were compiled in Microsoft Excel. On basis of these, maps of surface variations in the thickness of the ice, snow and slush layer, and snow-ice cover were prepared. In parallel, the data was used to calculate the Pearson correlation coefficient between the thickness of the lake ice layer and the thickness of the layer of snow and slush lying on the ice cover at the points studied (Tables 4,5 ). The study data had a normal distribution, which was tested using the nonparametric Kolmogorov-Smirnov test. Meanwhile, the level of statistical significance of the existing relationships was tested using Student's t-test. In addition, the maximum and minimum values were determined, and the arithmetic means of the ice cover and the snow layer accumulated thereon were calculated for each lake in the individual measurement series. Based on the isopach maps prepared, the volumes of the 
Table 4 Volume of the snow-ice cover on the study lakes in the 2017/2018 winter season.

\begin{tabular}{|c|c|c|c|c|c|c|c|c|c|c|c|c|c|c|c|}
\hline 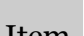 & I & & & & & & Sta & rt of seas & on & & & & & & \\
\hline Item & $\mathrm{L}$ & $\operatorname{Min}_{\mathrm{IT}}$ & MaxIT & $\mathrm{Av}_{\mathrm{IT}}$ & $\operatorname{Min}_{S \& S T}$ & Maxs\&ST & Avs\&ST & MinsICT $_{\text {SI }}$ & MaxsICT & Avsict & $\mathrm{IC}_{\mathrm{C}}$ & $\mathrm{SS}_{\mathrm{c}}$ & $\mathrm{SIC}_{\mathrm{c}}$ & $\mathrm{C}_{\text {Ic }}$ & $\mathrm{C}_{\text {SIC }}$ \\
\hline 1 & Morskie Oko & 15.0 & 31.0 & 25.1 & 15.0 & 46.0 & 27.1 & 34.0 & 63.0 & 52.2 & 87.5 & 83.9 & 171.4 & 0.9 & 1.7 \\
\hline 2 & $\begin{array}{l}\text { Czarny Staw } \\
\text { pod Rysami }\end{array}$ & 51.0 & 64.0 & 56.2 & 34.0 & 74.0 & 52.0 & 88.0 & 134.0 & 108.2 & 114.4 & 110.6 & 225.0 & 1.5 & 2.9 \\
\hline 3 & $\begin{array}{l}\text { Czarny Staw } \\
\text { Gąsienicowy }\end{array}$ & 50.0 & 110.0 & 80.8 & 25.0 & 78.0 & $45 \cdot 7$ & 78.0 & 164.0 & 126.5 & 135.6 & 73.1 & 208.7 & 73.6 & $5 \cdot 5$ \\
\hline 4 & $\begin{array}{l}\text { Smreczyński } \\
\text { Staw }\end{array}$ & 16.0 & 30.0 & 22.9 & 10.0 & 26.0 & 20.5 & 40.0 & 47.0 & 43.4 & 1.4 & 1.5 & 2.9 & 10.3 & 321.4 \\
\hline 5 & $\begin{array}{l}\text { Przedni Staw } \\
\text { Polski }\end{array}$ & 37.0 & 60.0 & 44.1 & 11.2 & 16.0 & 7.0 & 44.0 & 76.0 & $55 \cdot 3$ & $35 \cdot 3$ & 9.1 & 44.4 & 3.1 & 3.9 \\
\hline 6 & $\begin{array}{l}\text { Wielki Staw } \\
\text { Polski }\end{array}$ & 36.0 & 80 & $47 \cdot 3$ & 2.0 & 13.0 & 4.6 & 40.0 & 93.0 & 51.9 & 162.1 & 18.5 & 181.9 & 1.3 & 1.4 \\
\hline 7 & $\begin{array}{l}\text { Zadni Staw } \\
\text { Polski }\end{array}$ & 36.0 & 97.0 & 73.7 & 7.0 & 18.0 & 11.5 & 45.0 & 110.0 & 85.2 & 52.0 & 7.9 & 59.9 & $5 \cdot 7$ & 6.5 \\
\hline Item & Lake & & & & & & En & d of seasc & & & & & & & \\
\hline nem & Lake name & MinIT & MaxIT & Avit & Mins\&ST & Maxs\&ST & Avs\&st & Minsict & Maxs & Avsict & $\mathrm{ICC}_{\mathrm{C}}$ & $\mathrm{SS}_{\mathrm{c}}$ & $\mathrm{SIC}_{\mathrm{c}}$ & $\mathrm{C}_{\text {Ic }}$ & CsIC \\
\hline 1 & Morskie Oko & 36.0 & 62.0 & 50.7 & 0.0 & 13.0 & $3 \cdot 5$ & 43.0 & 62.0 & 54.2 & 169.3 & 8.6 & 177.9 & 1.7 & 1.8 \\
\hline 2 & $\begin{array}{l}\text { Czarny Staw } \\
\text { pod Rysami }\end{array}$ & 90.0 & 106.0 & 98.0 & 24.0 & 36.0 & 30.6 & 119.0 & 135.0 & 128.6 & 196.1 & 62.0 & 258.1 & 2.5 & $3 \cdot 3$ \\
\hline 3 & $\begin{array}{l}\text { Czarny Staw } \\
\text { Gąsienicowy }\end{array}$ & 31.0 & 84.0 & 43.0 & 0.0 & 0.0 & 0.0 & 31.0 & 84.0 & 43.0 & 70.4 & 0.0 & 70.4 & 1.9 & 1.9 \\
\hline 4 & $\begin{array}{l}\text { Smreczyński } \\
\text { Staw }\end{array}$ & nd. & nd. & nd. & nd. & nd. & nd. & nd. & nd. & nd. & nd. & nd. & nd. & nd. & nd. \\
\hline 5 & $\begin{array}{l}\text { Przedni Staw } \\
\text { Polski }\end{array}$ & 72.0 & 220.0 & 111.6 & 18.0 & 35.0 & 25.9 & 90.0 & 249.0 & 137.5 & 90.7 & 20.7 & 111.4 & 8.0 & 9.9 \\
\hline 6 & $\begin{array}{l}\text { Wielki Staw } \\
\text { Polski }\end{array}$ & 60.0 & 105.0 & 75.2 & 19.0 & 44.0 & 25.0 & 81.0 & 129.0 & 100.2 & 259.4 & 88.4 & 347.8 & 32.0 & 2.7 \\
\hline 7 & $\begin{array}{l}\text { Zadni Staw } \\
\text { Polski }\end{array}$ & 46.0 & 267.0 & 114.6 & 2.0 & 2.0 & 2.0 & 48.0 & 116.6 & 269.0 & 86.9 & 1.4 & 88.3 & 9.5 & 9.6 \\
\hline
\end{tabular}

Notes: nd.-No data; Min IT $_{-}$Minimum ice thickness (cm); Max IT - Maximum ice thickness (cm); AvIT - Average ice thickness (cm); Mins\&sT - Minimum snow and slush thickness (cm); Maxs\&st - Maximum snow and slush thickness (cm); Avs\&st - Average snow and slush thickness (cm); Minsict - Minimum snow-ice cover thickness (cm); Maxsict Maximum snow-ice cover thickness (cm); Avsict - Average snow-ice cover thickness (cm); ICc - Ice cover volume $\left(1 \cdot 10^{3} \mathrm{~m}^{3}\right) ; \mathrm{SS}_{\mathrm{c}}-$ Snow/slush cover volume $\left(1 \times 10^{3} \mathrm{~m}^{3}\right) ; \mathrm{SIC}_{\mathrm{c}}-$ Snow-ice cover volume $\left(1 \times 10^{3} \mathrm{~m}^{3}\right)$; $\mathrm{C}_{\mathrm{Ic}}-$ Percentage of lake volume occupied by ice cover (\%); CSIC (\%) - Percentage of lake volume occupied by snow-ice cover (\%).

Table 5 Values of the Pearson correlation coefficient between the snow and ice thicknesses at the measuring points

\begin{tabular}{l|l|l} 
Lake name & \multicolumn{2}{|c}{ Correlation coefficient } \\
\cline { 2 - 3 } Czarny Staw Gąsienicowy & Start of the season & End of the season \\
\hline Czarny Staw Pod Rysami & $0.453(p=0.090)$ & No snow cover \\
Morskie Oko & $0.540(p=0.038)$ & $0.289(p=0.636)$ \\
\hline Smreczyński Staw & $-0.749(p=0.000)$ & No snow cover \\
Przedni Staw Polski & $-0.867(p=0.001)$ & No data \\
Wielki Staw Polski & $0.830(p=0.003)$ & $0.476(p=0.165)$ \\
\hline Zadni Staw Polski & $0.948(p=0.000)$ & $0.449(p=0.193)$ \\
\hline
\end{tabular}

Notes: 0.830 - correlations statistically significant; 0.476 - correlations not statistically significant.

ice and snow-ice covers were calculated, and their percentage shares relative to the total volume of the lake were determined (Table 4). All the statistical calculations were made using Statistica1oPL software.

The duration of the ice phenomena on the lakes studied in the 2017/2018 season was determined from the analysis of the results of Landsat- 8 and
Sentinel-2 images from October 2017 to May 2018 and of field observations. The compositions of Naturalcolour and NDWI spectral channels with resolutions of $30 \mathrm{~m}$ (Landsat) and $20 \mathrm{~m}$ (Sentinel-2) used in the paper were sourced from: https://apps.sentinel-hub.com. Under the expression ice cover author means the situation, when $100 \%$ of the lake surface has been covered by ice. The 
situation, when ice is present in the water of the lake but does not cover entire surface of the lake is called ice phenomena. Accuracy of determining the appearance and disappearance of the ice phenomena and ice cover is: 1 day for Morskie Oko and Przedni Staw Polski, 3-4 days for other lakes.

To illustrate the weather conditions in the study area a matrix of air temperature, precipitation, snow cover and wind speed and direction was compiled covering the period from 1 October 2017 to 31 May 2018. The data came from three weather stations located in the same valleys as the study lakes (except Smreczyński Staw) and one at the summit of Kasprowy Wierch. The three valley stations include: i) Hala Gąsienicowa at ca. $1530 \mathrm{~m}$ a.s.l., $1.5 \mathrm{~km}$ north of Czarny Staw Gąsienicowy (1620 m a.s.l.); ii) Dolina Pięciu Stawów (1671 m a.s.l.) just $0.1 \mathrm{~km}$ from Przedni Staw (1668 m a.s.l.), $0.5 \mathrm{~km}$ from Wielki Staw (1665 m a.s.l.) and $2.5 \mathrm{~km}$ from Zadni Staw (1890 $\mathrm{m}$ a.s.l.); and finally iii) Dolina Rybiego Potoku (1400 m a.s.l.) located at a straight-line distance of $0.1 \mathrm{~km}$ to the north of Morskie Oko (1393 m a.s.l.) and $1.1 \mathrm{~km}$ from Czarny Staw Pod Rysami (1580 m a.s.l.). To better understand the weather around Zadni Staw the authors used records from the Kasprowy Wierch weather station (1987 m a.s.l.) located $3.0 \mathrm{~km}$ to the north of the lake and just short of 100 metres above. The Pearson correlation coefficient was used to correlate the weather data which was first checked for distribution using the Kolmogorov-Smirnov test. The level of statistical significance of the existing relationships was tested using Student's t-test.

\section{Results}

\subsection{Meteorological features}

The weather station matrix suggests that all parts of the study area followed a very similar temperature profile (Figure 2).

This is corroborated by the Pearson correlation coefficient values that ranged from $r=$ $0.95(p=0.000)$ for temperature comparisons between the Morskie Oko and Kasprowy Wierch stations, to $r=0.99(p=0.000)$ for temperatures between those from the Hala Gąsienicowa and Dolina Pięciu Stawów stations. The air temperature dropped with altitude. During the ice build-up period, i.e. from 1 November to $31 \mathrm{March}$, it ranged from $-4.2^{\circ} \mathrm{C}$ (Morskie Oko), to $-4.4^{\circ} \mathrm{C}$ (Hala Gąsienicowa), to $-5.4^{\circ} \mathrm{C}$ (Dolina Pięciu Stawów) and $-7.0^{\circ} \mathrm{C}$ (Kasprowy Wierch). The values followed a similar pattern during the period from 1 October to 31 May, when the average air temperatures were: $0.0^{\circ} \mathrm{C}$ (Morskie Oko), $-0.2^{\circ} \mathrm{C}$ (Hala Gąsienicowa), $-1.1^{\circ} \mathrm{C}$ (Pięć Stawów) and $-3.0^{\circ} \mathrm{C}$ (Kasprowy Wierch).

Precipitation values also revealed significant relationships between the weather stations. They ranged from $r=0.75(p=0.001)$ (Morskie OkoKasprowy Wierch) to $r=0.90 \quad(p=0.001)$ (Hala Gąsienicowa - Kasprowy). During the ice build-up period, precipitation totals were recorded as follows: $400.4 \mathrm{~mm}$ (Hala Gąsienicowa), $450 \mathrm{~mm}$ (Morskie Oko), 460 mm (Dolina Pięciu Stawów) and $470 \mathrm{~mm}$ (Kasprowy Wierch), which was reflected in the values of the snow cover thickness (Figure 2). The maximum snow cover thickness ranged from $121 \mathrm{~cm}$ at Hala Gąsienicowa to $280 \mathrm{~cm}$ on Kasprowy Wierch (Figure 2).

During the research season, the prevailing winds in the valleys were coming from the southern sectors. Southwestern and southern winds were the most frequent, followed by southeastern winds (Figure 2). The average wind speeds of the ice build-up period ranged from $2.5 \mathrm{~m} \mathrm{~s}^{-1}$ (Morskie Oko), to $3.6 \mathrm{~m} \mathrm{~s}^{-1}$ (Hala Gąsienicowa), $4.5 \mathrm{~m} \mathrm{~s}^{-1}$ (Dolina Pięciu Stawów) and $6.8 \mathrm{~m} \mathrm{~s}^{-1}$ (Kasprowy Wierch).

\subsection{Variability of the thickness of snow-ice cover}

Based on the network of drill holes made with a hand drill, it was found that the maximum (267.0 $\mathrm{cm})$ and minimum $(46.0 \mathrm{~cm})$ thicknesses of the ice may occur in different sections of the lake surface during one winter season, and that the difference in the thickness for the lakes examined may be as high as 221.0 cm (Figures 3, 4, 5). Variations in the ice thickness do not only pertain to the location on the lake surface, but also to the time when ice develops on the individual lakes. The results of measurements based on two series of observations, spanning a period of several months, were used to conduct a comparative analysis and an assessment of the dynamics of ice cover changes. 

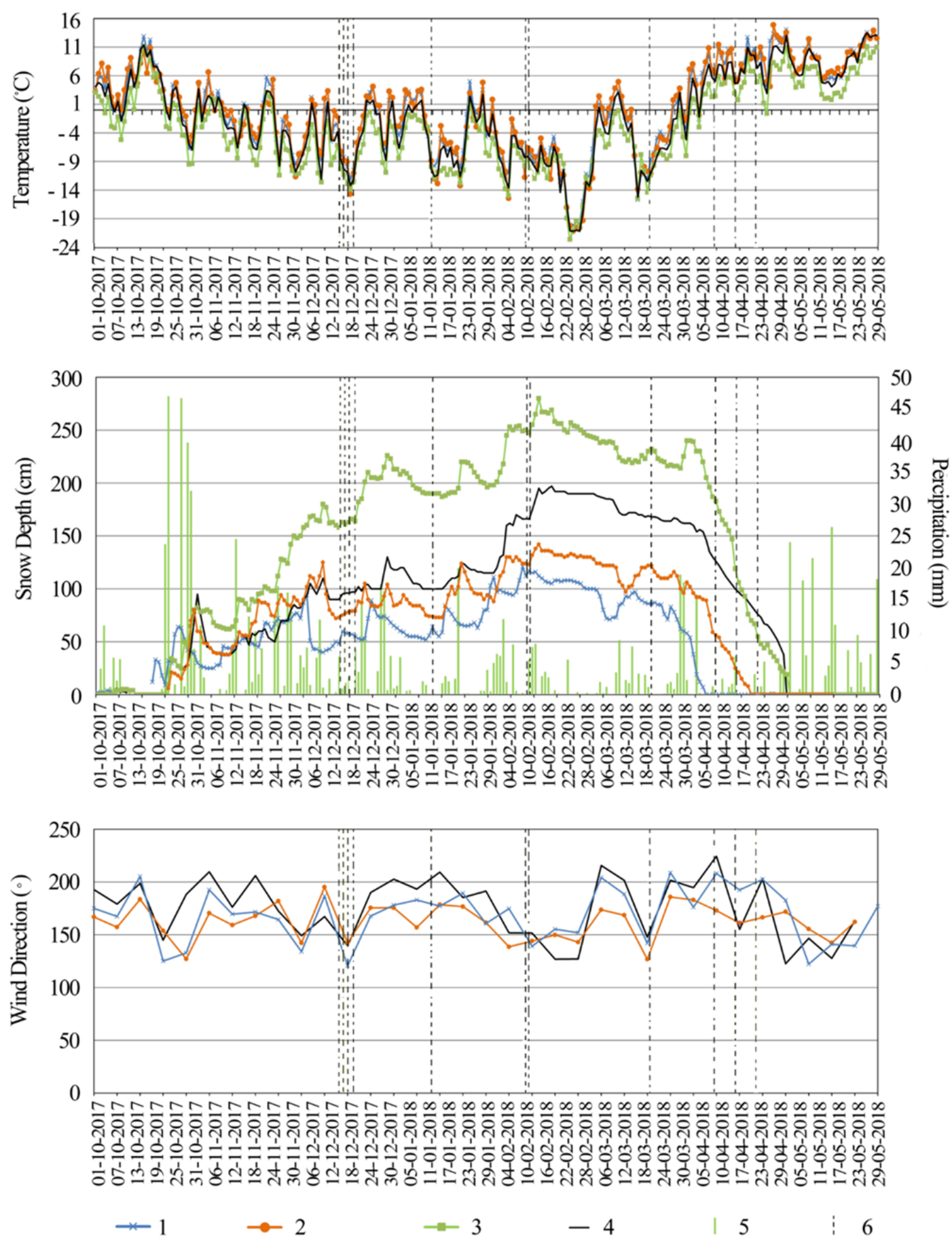

Figure 2 Weather conditions during the research season: 1 - Hala Gąsienicowa, 2- Morskie Oko, 3 - Kasprowy Wierch, 4 - Dolina Pięciu Stawów Polskich, 5 - Kasprowy Wierch (precipitation), 6 - fieldwork dates.

\subsubsection{Smreczyński Staw}

In December 2017, the average ice thickness was $22.9 \mathrm{~cm}$ with substantial differences between the minimum and maximum values (Figure 3 ). The winter (snow-ice) cover did not demonstrate such pronounced differences $(7 \mathrm{~cm}$ ) (Figure 5). The highest value of maximum ice thickness was recorded near the north, northeast and southwest shores of the lake, while the lowest was found in its central and western areas (Figure 3). The ice thickness was greatest where the thickness of the snow cover was the smallest (Table 5). The volume of the ice cover lying on the lake at the beginning of 

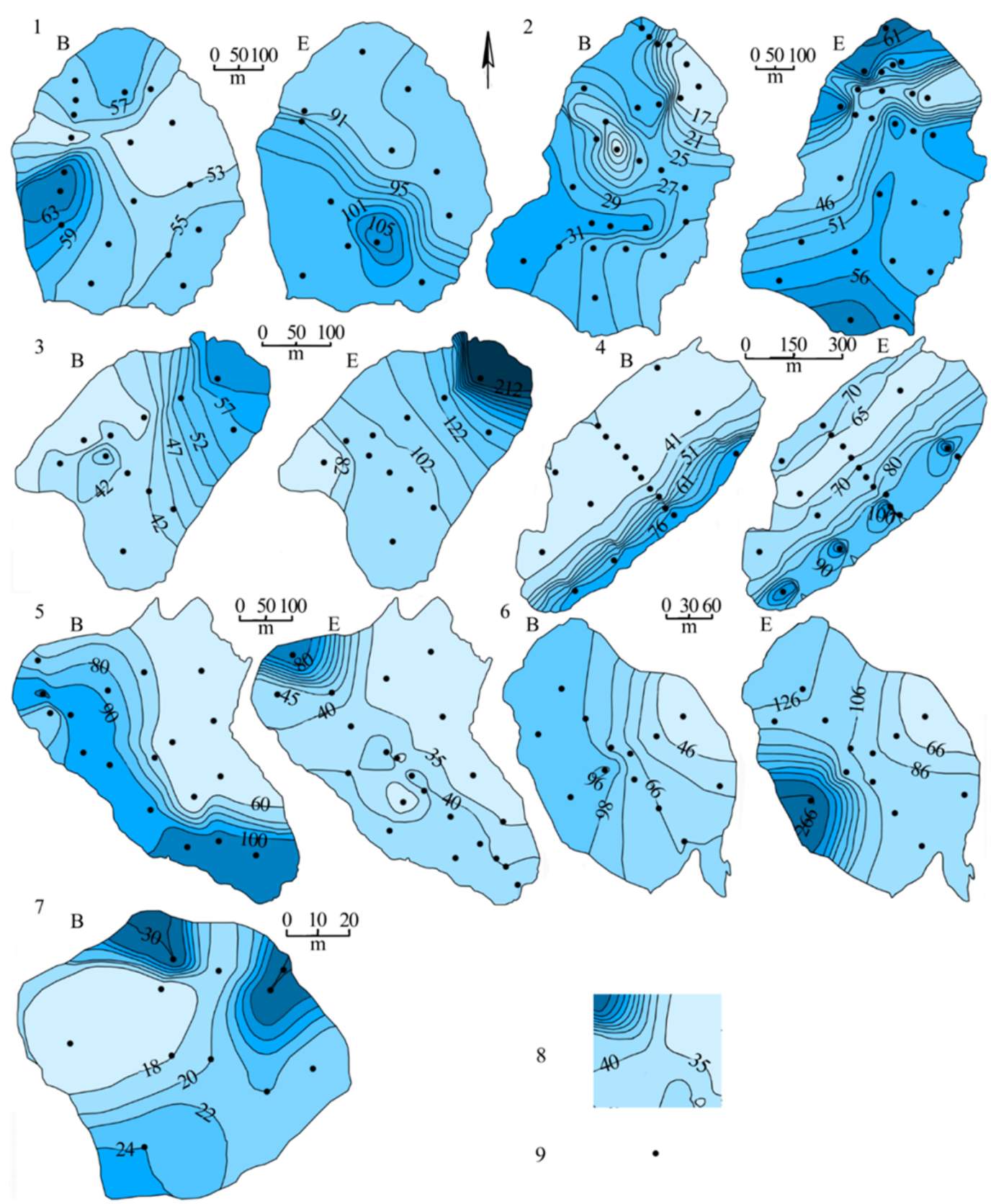

6 - Zadni Staw Polski, 7 - Smreczyński Staw, 8 - isopachytes of ice (cm), 9 - drilling points; B - Beginning of the winter season, E- End of the winter season.

Figure 3 Spatial differentiation of ice cover thickness in the winter season 2017/2018.

the season was $1.4 \times 10^{3} \mathrm{~m}^{3}$, which represented nearly half the volume of the snow-ice cover and $10.3 \%$ of the volume of the lake waters (Table 4).

\subsubsection{Morskie Oko}

In the winter season 2017/2018, the lake's ice cover was characterised by significant variations (15.0-31.0) $\mathrm{cm}$. The greatest maximum ice thickness, which was recorded in April, was 62.0 $\mathrm{cm}$ (Figure 3), i.e. twice the size of the cover observed at the beginning of the winter season. In the period from December to April the variations in ice thickness changed on the lake's surface. The maximum ice cover thickness in December was found off the north and southwest shores of the lake, while in April it was found on the north and south areas of the lake (Figure 3). In general, there was an observable increase in the thickness of the 


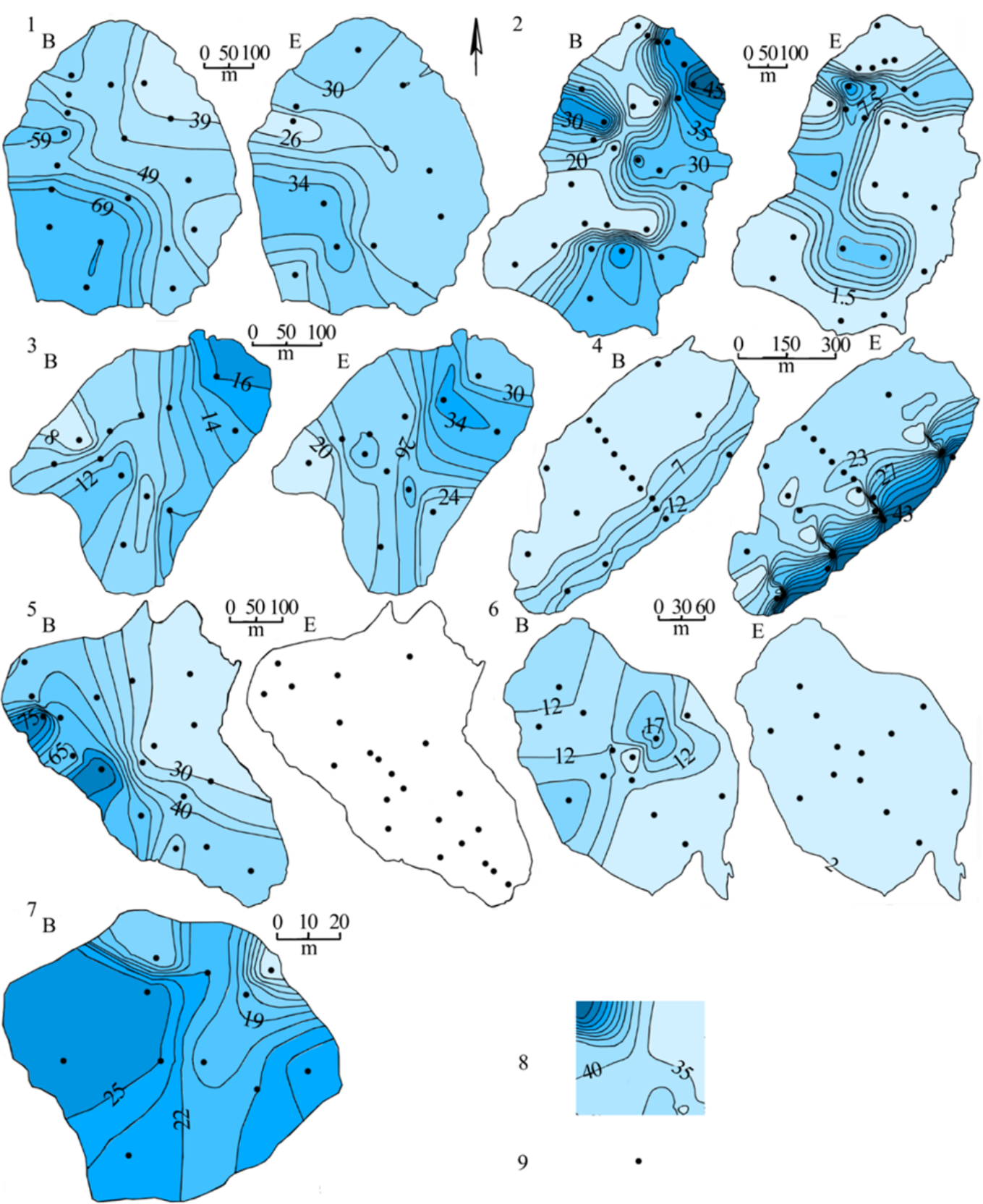

1 - Czarny Staw Pod Rysami, 2 - Morskie Oko, 3 - Przedni Staw Polski, 4 - Wielki Staw Polski, 5 - Czarny Staw Gąsienicowy, 6 - Zadni Staw Polski, 7 - Smreczyński Staw, 8 - isopachytes of snow (cm), 9 - drilling points, B - Beginning of the winter season, E- End of the winter season.

Figure 4 Spatial differentiation of snow cover thickness in the winter season 2017/2018.

winter (snow-ice) cover from the north to the south (with the exception of the northern shore area) (Figure 5). In December, the average thickness of the snow cover was almost the same as that of the ice cover. In April, it was only $3.5 \mathrm{~cm}$ thick and was characterised by greater variations, and its thickness was 14.5 times smaller than the thickness of the ice (Figure 4). At the beginning of the season, the volume of the lake's ice cover was $87.5^{\times 10^{3}} \mathrm{~m}^{3}$, which accounted for $0.9 \%$ of the volume of the lake waters, while towards the end of the season, it was $169.3 \times 10^{3} \mathrm{~m}^{3}$, i.e. $1.7 \%$ of the lake's volume (Table 4 ).

\subsubsection{Czarny Staw pod Rysami}

In February, the spatial variability in the ice cover on the lake was inconsiderable (from $51.0 \mathrm{~cm}$ to $64.0 \mathrm{~cm}$ ) in contrast to the differences in the snow cover (from $34.0 \mathrm{~cm}$ to $74.0 \mathrm{~cm}$ ). Incidentally, 
the areas of variation in the ice and snow covers nearly overlapped (Figures 3, 4, 5). The minimum thickness of the ice cover was found in the northeastern part of the lake, while the maximum thickness in the western section of the lake (Figure 3). In April, the ice thickness continued to display low variability, and it averaged $98.0 \mathrm{~cm}$ and was about twice as large as the cover measured in February. In April, the average thickness of the snow cover and its variability decreased significantly. In the winter season 2017/2018, there was a clear increase in the thickness of the snow-ic e cover from the northeast to the southwest, with little variation (Figure 5). At the beginning of the season, the volume of the lake's ice cover was $114.4 \times 10^{3} \mathrm{~m}^{3}$, which accounted for $1.5 \%$ of the volume of water in the lake, while towards the end of the season it was $196.1 \times 10^{3} \mathrm{~m}^{3}$, i.e. $2.5 \%$ of the
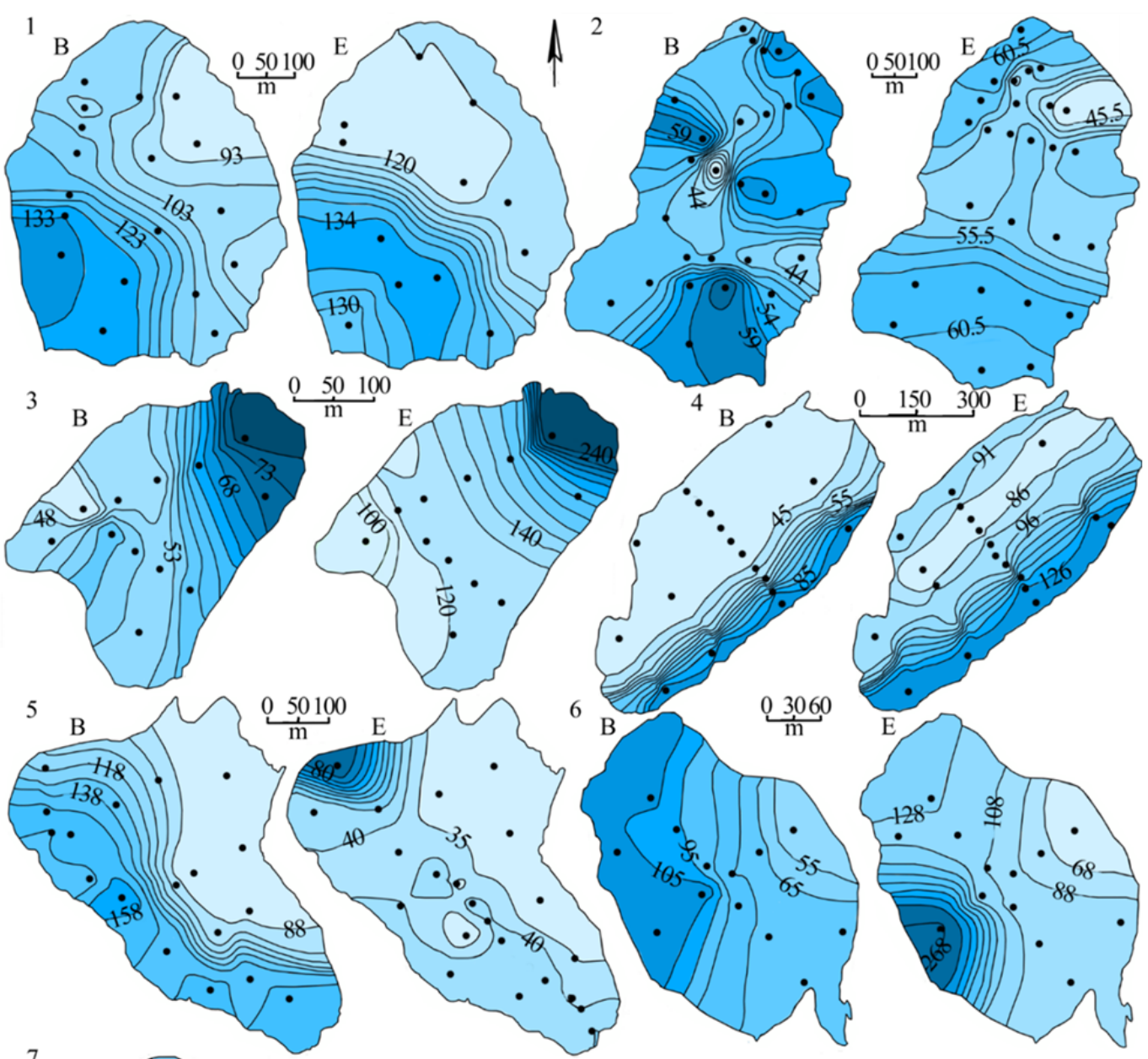

$\stackrel{0}{\frac{50}{\mathrm{~m}} 100}$
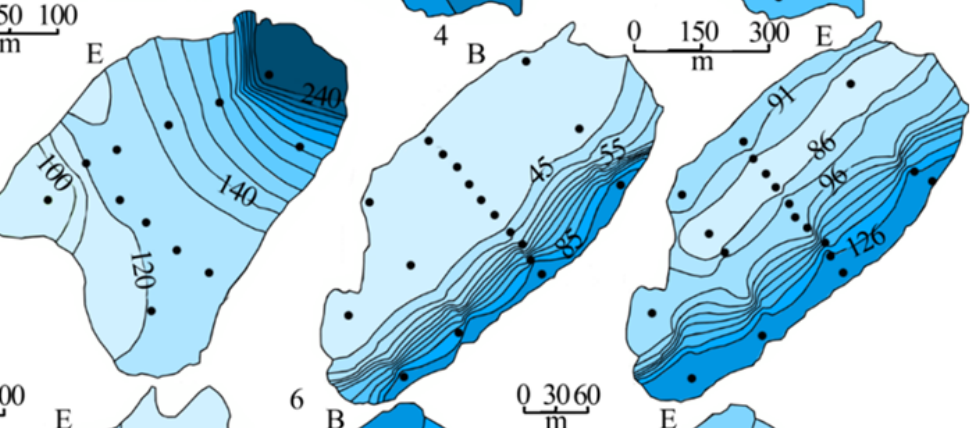

6
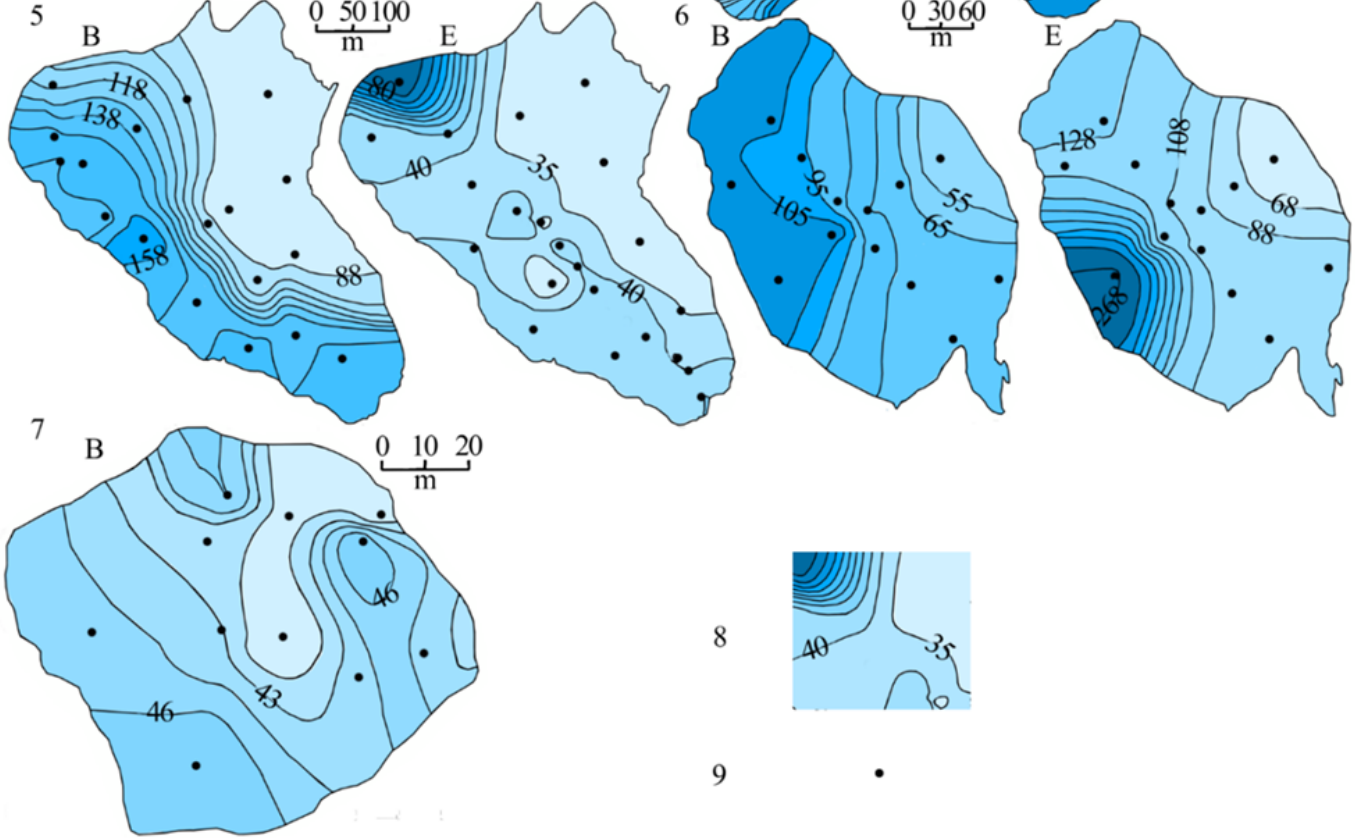

9

1 - Czarny Staw Pod Rysami, 2 - Morskie Oko, 3 - Przedni Staw Polski, 4 - Wielki Staw Polski, 5 - Czarny Staw Gąsienicowy, 6 - Zadni Staw Polski, 7 - Smreczyński Staw, 8 - isopachytes of snow-ice cover (cm), 9 - drilling points, B - Beginning of the winter season, E - End of the winter season.

Figure 5 Spatial differentiation of snow-ice cover thickness in the winter season 2017/2018. 
lake's water volume (Table 4).

\subsubsection{Czarny Staw Gasienicowy}

In February, the average thickness of the ice cover was $80.8 \mathrm{~cm}$ and was almost twice as large as the snow cover. Its spatial variability was considerable (from $50.0 \mathrm{~cm}$ to $110 \mathrm{~cm}$ ), and similar to that of the snow cover (from $25.0 \mathrm{~cm}$ to $78.0 \mathrm{~cm}$ ), and this persisted throughout the winter season (Figures 3, 4, 5). In April, the thickness of the ice decreased by half, with a complete absence of snow on the lake surface (Figures $3,4,5$ ). In the winter of 2017/2018, the thickness of the winter cover increased from the northeast to the south-west (Figure 5). In the first part of the season, the volume of the ice cover on the lake was $135.6 \times 10^{3}$ $\mathrm{m}^{3}$, which accounted for $3.6 \%$ of the volume of the lake waters, while towards the end of the season it was $70.4 \times 10^{3} \mathrm{~m}^{3}$, i.e. $1.9 \%$ of the volume of the lake waters (Table 4 ).

\subsubsection{Zadni Staw Polski}

In December 2017, the average thickness of the ice cover was $73.7 \mathrm{~cm}$, but its spatial variability was very high (Figure 3). In the same period, the average snow thickness was $11.5 \mathrm{~cm}$ with little variation in the snow cover (Figure 4). In April, the snow cover disappeared nearly completely, shrinking to $2 \mathrm{~cm}$, and there was an increase in the spatial variability in the thickness of the ice cover $(221.0 \mathrm{~cm}$ ) on the lake (Figures $3,4,5)$. At that time, the highest value of maximum ice thickness on the lakes examined was recorded in the winter season 2017/2018 $(267 \mathrm{~cm})$ off the south-west shore (slope of Walentkowy Wierch). The ice thickness increased from the east westwards (Figure 5). In the first part of the season, the volume of the lake's ice cover was $52.0 \times 10^{3} \mathrm{~m}^{3}$, which accounted for $5.7 \%$ of the water volume of the lake, while towards the end of the season it was $86.9 \times 10^{3} \mathrm{~m}^{3}$, i.e. $9.5 \%$ of the lake's water volume (Table 4).

\subsubsection{Przedni Staw Polski}

In December 2017, the average ice thickness was $44.1 \mathrm{~cm}$ and displayed moderate spatial variability (Figure 3). The snow cover was characterised by low thickness $(7.0 \mathrm{~cm}$ on average) and very small variations $(4.8 \mathrm{~cm})$ (Figure 4$).$ On 20 March 2018, the maximum thickness of the ice was $220.0 \mathrm{~cm}$ (Figure 3). There was also a large increase in the spatial variability of the ice thickness on the lake on that day $(148 \mathrm{~cm})$. The average thickness of snow $(25.9 \mathrm{~cm})$ and spatial differentiation of its thickness $(17.0 \mathrm{~cm})$ increased (Figure 4). The thickness of the snow-ice cover increased from west to north-east and reached its maximum in March in the northern section of the lake $(249.0 \mathrm{~cm})$ (Figure 5). In the first part of the season, the volume of the lake's ice cover was $35.3 \times 10^{3} \mathrm{~m}^{3}$, which accounted for $3.1 \%$ of the water volume of the lake, while towards the end of the season it was $90.7 \times 10^{3} \mathrm{~m}^{3}$, i.e. $8.0 \%$ of the lake's water volume (Table 4).

\subsubsection{Wielki Staw Polski}

Overall, throughout the winter season 2017/2018, the thickness of the ice cover varied greatly and increased from northwest to southeast (Figure 3). In January, the average ice thickness was $47.3 \mathrm{~cm}$, with considerable spatial variation (Figure 3). The snow cover was not thick $(4.6 \mathrm{~cm}$ on average) and did not show major spatial variations $(11.0 \mathrm{~cm}$ ) (Figure 4). March saw an increase in the thickness of the ice and snow covers and in the spatial variability in their thickness (Figures 3, 4). The trend of spatial increase in the thickness of ice and snow from north-west to south-east persisted (Figure 5). The greatest maximum ice thickness in the winter season 2017/2018 was recorded along the eastern shores of the lake (slopes of Miedziany Szczyt) (Figure 3). In the first part of the season, the volume of the lake's ice cover was $162.1 \times 10^{3} \mathrm{~m}^{3}$, which accounted for $1.3 \%$ of the water volume of the lake, while towards the end of the season it was $259.4 \times 10^{3} \mathrm{~m}^{3}$, i.e. $2.0 \%$ of the lake's water volume (Table 4 ).

\subsection{Correlations}

The data obtained were used as the basis for determining the relationship between the thickness of the ice cover and the thickness of the snow layer. In terms of the size and directions of the dependencies, the correlation coefficients were varied and statistically significant only for the measurements of snow and ice taken at the beginning of the 2017/2018 winter season (Table 5). In the case of the Morskie Oko and Smreczyński Staw lakes, the dependencies were strong and inverse, which means that a thick layer of snow covered relatively thin ice. Measurements on these 
reservoirs were made at the very beginning of the winter season (December). Substantial relationships were also recorded in the case of Przedni Staw Polski and Wielki Staw Polski, but they were directly proportional, which means that thick snow covered correspondingly thick ice (Table 5). Measurements on these lakes were taken in December and January. Moderate correlations were found for Czarny Staw Gąsienicowy and Czarny Staw Pod Rysami, but they were statistically significant only for the latter (Table 5). The thickness of the snow-ice cover on these lakes was investigated in February. Weak and statistically insignificant correlations were found for the measurements made for the layer of snow and ice lying on Zadni Staw Polski. In the second part of the season, the relationship between the snow cover thickness and ice sheet thickness was much weaker and statistically non-significant (Table 5).

\subsection{Duration of ice phenomena}

Ice first appeared on Morskie Oko on 13 November and two days later, on 15 November, the entire surface of the lake was frozen. The full ice cover lasted until 10 April and ice phenomena continued until 18 April. This means that ice phenomena lasted for 157 days and the full cover for 147 days. According to IMGW (the Polish national weather service) data, the ice reached its maximum thickness of $85.0 \mathrm{~cm}$ on 31 March.

On Czarny Staw Pod Rysami the ice phenomena started on 11 November and the ice cover on 15 November. This started breaking up on 26 April and the ice phenomena disappeared on 8 May. This puts the duration of the ice phenomena at 179 days and the ice cover at 163 days.

The ice phenomena on Czarny Staw Gąsienicowy started on 11 November and the ice cover on 14 November. This started breaking up on 21 April and the ice phenomena disappeared on 5 May. This puts the duration of the ice phenomena at 176 days and the ice cover 159 days.

The ice phenomena on Smreczyński Staw appeared on 10 November and the ice cover on 12 November. This started breaking up on 8 April and the ice phenomena disappeared on 23 April. This puts the duration of the ice phenomena at 165 days and the ice cover 148 days.

The ice cover on Zadni Staw Polski developed on 9 November and broke up on 3 May 2018, lasting for 175 days. The ice phenomena on this lake were the most persistent of all the lakes and continued until 19 May.

The ice cover on Wielki Staw Polski developed on 9 December and broke up on 10 April lasting for 122 days.

The ice cover on Przedni Staw developed on 16 November and broke up on 28 April, lasting for 163 days.

\section{Discussion}

The amount of snow supplied and its redistribution by wind is the main factor behind the surface variability of the thickness of the ice cover on the lakes in the Tatras. This is connected with the fact that crystalline ice, which forms chiefly at the lake freezing stage, tends to represent only a few per cent of the thickness of the ice cover on these lakes (Choiński 2007a,b, 2016). In the subsequent stages of ice thickening, the key factor behind the ice growth is the addition of snow ice from the top (Leppäranta 1983, 2009; Solarski et al. 2011; Leppäranta 2015; Solarski 2017). Thus, an uneven distribution of snow leads to differences in ice thickening (Adams and Shaw 1967; Adams and Roulet 1980, 1984; Adams 1981, 1982, 1984; Bengtsson 1986). The highest values of ice thickness during the 2017/2018 winter were found at the points where snowdrifts had previously accumulated, while the lowest were in the areas where snow had been blown away (Figures 3, 4, 5). The delivery of snow onto the surface of the lakes through avalanches of various sizes provided another important factor contributing to the variability of the snow and the thickness of the ice cover on most of the lakes in the study. Indeed, the greatest thickness values were measured downslope from the avalanche tracks, where the snow masses released from the slopes were deposited (Žiak and Długosz 2015). On Czarny Staw Pod Rysami this was in the south-western sector (at the foot of Mt Kazalnica Mięguszowiecka). On Czarny Staw Gąsienicowy it was its western and north-western part (at the foot of Mt Kościelec and Przelęcz Karb). On the lakes in Dolina Pięciu Stawów these were either on the southern (Wielki Staw on the side of Mt Miedziany, Przedni Staw 
near Opalony Wierch) or western (Zadni Staw at the foot of the slopes of Walentkowy Wierch) parts of the lake surface (Figures 3, 4, 5). In contrast, Morskie Oko and Smreczyński Staw, being more distant from avalanche-prone slopes, revealed no traces of avalanche deposition during the research period.

Local surface variations in ice thickness are also influenced by the density and orientation of cracks in the ice cover (ice tectonics) (Aihara et al. 2010; Choiński 2010). Near the ice cracks and crevices, the snow cover that accumulated on the ice was saturated with water. At times when the air temperature drops considerably, the thus formed layer of slush freezes creating a layer of snow ice, causing the thickness of the ice cover to increase locally (Aihara et al. 2010; Choiński 2010). There is already intensive formation of cracks and crevices on the Tatra lakes at the ice cover formation stage as a result of changes in the volume of ice under the influence of varying air temperatures. The process leads to a growth in the variations of ice thickness during the later stages of ice development. Ohlendorf et al. (2000) and Choiński (2007b) also drew attention to the role of topography in the formation and withdrawal of ice from Alpine lakes. Research conducted on the Tatra lakes during the 2017/2018 winter proves that the topography of the area around the lake basin influences the variations in the thickness of ice and the rate of its disintegration and retreat in spring. The largest ice thicknesses were found in those parts of the lakes, which were sheltered from solar radiation by the rocky faces of mountain ridges (Figure 3). In such areas, ice ablation proceeded at the slowest pace in spring. In the light of data on the potential annual insolation (Wojkowski 2015), the areas receiving the least solar energy include Czarny Staw Pod Rysami (entire lake), the southern part of Morskie Oko (at the foot of Mięguszowieckie Szczyty) and the south-western part of Czarny Staw Gąsienicowy (at the foot of Mt Kościelec). These areas receive no more than $1750 \mathrm{~h} \mathrm{a}^{-1}$ of potential annual insolation while elsewhere on the study lakes it ranges from 2000 to $3000 \mathrm{~h} \mathrm{a}^{-1}$.

Morskie Oko is the best investigated lake as regards the spatial differentiation of the thickness of the ice cover (Choiński 2007a, b; Choiński et al. 2013). Studies on the surface variability of ice thickness on this mountain lake have been conducted since 2006 (Table 1). Since that date, researchers have made eight measurement expeditions, during which they have made 160 drills in the lake's ice sheet (Choiński et al. 2013). As shown by the research, the lake has shown considerable differences in the conditions of lake ice development from one winter to another, and the surface variation of the ice cover has been small $(3 \mathrm{~cm})$ or very large $(31 \mathrm{~cm})$ (Choiński 2007a, b; Choiński et al. 2013). Choiński (2007a, b) and Choiński et al. (2013) identified smaller differences in the thickness in their research carried out at the beginning of the ice season. The greatest variations in ice cover thickness $(31.0 \mathrm{~cm})$ were found by investigations carried out at the end of the first decade of May 2006. This confirms the observations made during research on the spatial differentiation of ice thickness on the Tatra lakes conducted in the 2017/2018 winter season. The differences in ice thickness increased during the winter season on account of the uneven addition of snow ice from the top of the ice cover (Figures 3, 4, 5).

In general, the volume of the ice and snow-ice covers grew during the winter season, which also translated into an increase in the percentage of both layers in the total volume of the lakes studied. Only in the case of Czarny Staw Gąsienicowy, where the second series of measurements was performed in the advanced ablation phase, had the volume of the ice and snow-ice covers declined (Table 4). The largest volume of the ice and snowice covers was calculated for Wielki Staw Polski, which is not much bigger in terms of area than Morskie Oko and is located nearly 300 metres higher (Table 4). As is demonstrated by the research of Choiński et al. (2014), in the years 2006-2013, which involved nine series of measurements, the volume of ice on Morskie Oko ranged from $111.2 \cdot 10^{3} \mathrm{~m}^{3}$ (1.1\% of the lake's water resources) to $266.7 \cdot 10^{3} \mathrm{~m}^{3}$ (2.5\% of the lake's volume). These values are similar to those measured on this lake in the 2017/2018 winter season (Table 3).

The ice and snow-ice covers constituted only a few per cent of the water volume of the study lakes, which results from their morphometric features: considerable average and maximum depths, which in turn translate into the amount of lake waters retained in them. The exception is the small and shallow Smreczyński Staw (Table 4). 
A comparison of the Morskie Oko data for the 2014/2015 and 2016/2017 seasons (Gądek et al. 2020) plus those for $2017 / 2018$ and 1963-2012 (Pawłowski 2018) reveals a distinct trend to a reduction in duration for both ice cover and ice phenomena. In the season 2017/2018, the latter began developing five days earlier and the former ten days earlier than the long-term average (19632012), but ended as many as 23 and 28 days earlier, respectively. Similar trends are recorded in other mountains of Central Europe (Livingstone 1997).

In the winter of $2017 / 2018$, the ice cover on Morskie Oko was $16 \mathrm{~cm}$ thicker than the average for 1963-2012. This characteristic is less susceptible to the influence of climate-change and any change registered is not statistically significant (Ptak et al. 2017; Pawłowski 2018). The results of incidental ice thickness measurements made in the late $19^{\text {th }}$ and early $20^{\text {th }}$ century also do not significantly differ from the winter records of 2017/2018 (Table 1).

The long-term trends of ice phenomena on Morskie Oko correspond with the climate data. Over almost the last 70 years, the Tatra Mountains have experienced an increase in air temperature (Żmudzka 2011; Łupikasza and Szypuła 2019). This trend was significant from the 1980s (Eupikasza and Szypuła 2019), while the water temperature showed dynamic growth rates starting in 1997 (Zhu et al. 2020).

\section{Conclusions}

The results of the study suggest that snow cover plays a dominant role in the variability of the ice sheet thickness on the lakes surveyed in the study. The air temperature drop and the increase in snow cover with altitude translate into spatial variability in the thickness of lake ice cover. At the onset of the winter season, a thick snow cover may slow down the build-up of ice thickness on the water side, which in turn translates into a strong reverse correlation between the snow cover thickness and the thickness of the underlying ice. In subsequent stages, shifts in the weight of snow cover, due to snow being blown from place to place and, sometimes, also due to avalanche deliveries, may result in uneven pressure on the ice cover and local variability in the ice growth on the snow-cover side. The thickest snow and ice covers on the lakes in the study developed in the spots with the most snow accumulation.

The ice phenomena and ice covers tended to last longer on lakes located higher up, but the topography surrounding the lake bowl also played a role. Lake ice tended to last the longest on the parts of the lake surface most shaded by mountain slopes and cliffs.

Despite the great variability of the ice thickness on the study lakes, single point measurements have been shown to be useful for determining long-term trends in the ice conditions as long as the measurement points were consistently stable.

The number of days with ice phenomena and ice cover on Morskie Oko in 2017/2018 was much lower than the long-term average. The onset of the ice phenomena and cover came earlier, but their disappearance was brought much further forward, which mostly fits well with the trends of contemporary variability in ice patterns on lakes in the Central European mountains.

\section{Acknowledgements}

The authors would like to thank prof. Dr hab. Bogdan Gądek for valuable comments on the research and this work. At the same time, they would like to thank colleagues Kamil Kachniarz, Daniel Kołata, Arkadiusz Piwowarczyk, friend of Wiktoria Czuchraj for help in the field work, colleague Łukasz Potempka for consulting on the statistical methods used and the Management of the Tatra National Park for consent for research and logistic assistance.

Open Access This article is distributed under the terms of the Creative Commons Attribution 4.0 International License (http://creativecommons. org/licenses/by/4.o/), which permits unrestricted use, distribution, and reproduction in any medium, provided you give appropriate credit to the original author(s) and the source, provide a link to the Creative Commons license, and indicate if changes were made. 


\section{References}

Adams WP, Shaw JB (1967) Studies of ice cover on Knob Lake, New Québec. Cahiers de géographie du Québec 11: 88-96. https://doi.org/10.7202/020684ar

Adams WP, Roulet NT (1980) Illustration of the roles of snow in the evolution of the winter cover of a lake. Arctic 33: 100-116. https://doi.org/10.14430/arctic2550

Adams WP (1981) Snow and ice on lakes. In: Gray DM, Male DH (eds.), Handbook of Snow. Canada: Pergamon Press, New York, USA. pp 437-474.

Adams WP (1982) Spatial variability of snow and ice on lakes and a strategy in measurement based on three years' data from Elizabeth Lake. Labrador. Proceedings of Western Snow Conference, Reno, Nevada, USA. pp 49-62.

Adams WP (1984) Improving ice and snow measurements on lakes. Proc. Fifth Northern Research Basins Symposium, Vierumaki, Finland. 1.1-1.13.

Adams WP, Roulet NT (1984) Sampling of snow and ice on lakes. Arctic 37: 270-275. https://doi.org/10.14430/arctic2200

Ariano SS, Brown LC (2019) Ice processes on medium-sized north-temperate lakes. Hydrological Processes 33: 2434-2448. https://doi.org/10.1002/hyp.13481

Aihara M, Chikita KA, Momoki Y, et al. (2010): A physical study on the thermal ice ridge in a closed deep lake: Lake Kuttara, Hokkaido, Japan. Limnology 11: 125-132. https://doi.org/10.1007/s10201-009-0298-0

Andrews JT (1962) Variability of lake-ice growth and quality in the Schefferville region. Central Labrador-Ungava. Journal of Glaciology 4: 337-347. https://doi.org/10.3189/Soo22143000027660

Balon J, Jodłowski M, Krąż P (2015) Tatra Mountains Topography. In: Atlas of the Tatra Mountains. Abiotic Nature, sheet I.3, Tatra National Park, Zakopane, Poland.

Bengtsson L (1986) Spatial variability of lake ice covers. Geografiska Annaler. Series A, Physical Geography 68: 113121. https://doi.org/10.1080/04353676.1986.11880164

Birkenmajer LA (1901) The water temperatures of deep Tatra lakes in various depths and seasons. Rozprawy Akademii Umiejętności 40, Kraków, Poland. pp 186-411. (In Polish)

Borucki T (2005) A critical analysis of the Tatra itenerarium of Stanisław Staszic. In: Wójcik W (ed.), Place and significance of mountains in the work of Stanisław Staszic, Kraków, Poland. pp 79-135. (In Polish)

Bryan ML, Marcus MG (1972) Physical characteristics of nearshore ice ridges. Arctic 25: 182-192. https://doi.org/10.14430/arctic2960

Brown L, Duguay CR (2010) The response and role of ice cover in lake-climate interactions. Progress in Physical Geography 34: 671-704. https://doi.org/10.1177/0309133310375653

Choiński A, Gałka M, Ławniczak A (2006) Differentiations of the ice cover of selected lakes. Badania Fizjograficzne nad Polską Zachodnią Seria A 57: 15-20. (In Polish)

Choiński A (2007a) Examples of variation in ice cover thickness in mountain and lowland lakes in Poland. Limnological Review 7: 11-18.

Choiński A (2007b) Ice phenomena on the Morskie Oko Lake in the Tatra Mts.. Folia Geographica, Series GeographicaPhysica 37-38: 65-77.

Choiński A (2010) Ice phenomena on Lake Jamno. In: Choinski A (ed.), Changes of lakes and water bodies, Studia i Prace z Geografii i Geologii 10, Scientific Publisher Bogucki, Poznań, Poland. pp 33-42. (In Polish)

Choiński A, Kolendowicz L, Pociask-Karteczka J, Sobkowiak L (2010) Changes in lake ice cover on the Morskie Oko lake in Poland (1971-2007). Advances in Climate Change Research 1: 71-75. https://doi.org/10.3724/SP.J.1248.2010.00071

Choiński A, Ptak M (2012) Variation in the ice cover thickness on Lake Samołęskie as a result of underground water supply. Limnological Review 12: 133-138.

https://doi.org/10.2478/v10194-012-0053-5
Choiński A, Ptak M (2013) Variation of ice cover thickness of selected lakes in Greater Poland. Badania Fizjograficzne, Seria A 64: 29-37. (In Polish)

Choiński A, Ptak M, Strzelczak A (2013) Areal variation in ice cover thickness on lake Morskie Oko (Tatra Mountains). Carpathian Journal of Earth and Environmental Sciences 8: 97-102.

Choiński A, Pociask-Karteczka J, Ptak M, Strzelczak A (2014) Ice phenomena on the Morskie Oko. In: Choiński A, PociaskKarteczka J (eds.), Morskie Oko - Nature and Man. Tatra National Park, Zakopane, Poland. (In Polish)

Choiński A, Ptak M, Skowron R, et al. (2015a) Changes in ice phenology on Polish lakes from 1961-2010 related to location and morphometry. Limnologica 53: 42-49. https://doi.org/10.1016/j.limno.2015.05.005

Choiński A, Ptak M, Strzelczak A (2015b) Changeability of accumulated heat content in alpine-type lakes. Polish Journal of Environmental Studies 24: 2363-2369. https://doi.org/10.15244/pjoes/58871

Choiński A (2016) Ice phenomena on Lake Czarny Staw Pod Rysami. Limnological Review 16: 165-169. https://doi.org/10.1515/limre-2016-0018

Choiński A (2017) Ice phenomena on Wielki Staw in Valley of Five Polish Lakes. Limnological Review 17: 71-77. https://doi.org/10.1515/limre-2017-0007

Cox GFN (1984) A preliminary investigation of thermal ice pressures. Cold Regions Science and Technology 9: 221-229. https://doi.org/10.1016/0165-232X(84)90069-7

Duguay CR, Flato GM, Jeffries MO, et al. (2003) Ice cover variability on shallow lakes at high latitudes: model simulations and observations. Hydrological Processes 17: 3465-3483. https://doi.org/10.1002/hyp.1394

Falarz M (2002) The climatic causes of changes and long-term variability in the snow cover of the Polish Tatra Mountains. Przegląd Geograficzny 74: 83-106. (In Polish)

Fang X, Stefan HG (1998) Potential climate warming effects on ice covers of small lakes in the contiguous U.S. Cold Regions Science and Technology 27: 119-140. https://doi.org/10.1016/So165-232X(97)00027-X

Gao SB, Stefan HG (1999) Multiple linear regression for lake ice and lake temperature characteristics. Journal of Cold Regions Engineering 13: 59-77. https://doi.org/10.1061/(ASCE)o887-381X(1999)13:2(59)

Gądek B (2014) Climatic sensitivity of the non-glaciated mountains cryosphere (Tatra Mts., Poland and Slovakia). Global and Planetary Change 121 : 1-8. https://doi.org/10.1016/j.gloplacha.2014.07.001

Gądek B, Szumny M, Szypuła B (2020) Classification of the Tatra Mountain lakes in terms of the duration of their ice cover (Poland and Slovakia). Journal of Limnology 79: 70-81. https://doi.org/10.4081/jlimnol.2019.1920

Granados I, Toro M, Giralt S, Camacho A, et al. (2020) Water column changes under ice during different winters in a midlatitude Mediterranean high mountain lake. Aquatic Sciences 82. https://doi.org/10.1007/s00027-020-0699-z

Gregor V, Pacl J (2005) Hydrology of the Tatra Mountain lakes. Acta Hydrologica Slovaca, 6, pp 161-187. (In Slovak)

Greenbank J (1945) Limnological conditions in ice-covered lakes, especially as related to winter-kill of fish, Ecological Monographs, 15: 343-392. https://doi.org/10.2307/1948427

Hess M (1965) Climatic floors in the Polish Western Carpathians. Prace Gegraficzne 11, Kraków, Poland. (In Polish)

Hewitt A, Lopez LS, Gaibisels KM, et al. (2018) Historical Trends, Drivers, and Future Projections of Ice Phenology in Small North Temperate Lakes in the Laurentian Great Lakes Region. Water 10. https://doi.org/10.3390/w10010070

IMGW (Institute of Meteorology and Water Management) (2007) Map of hydrological division of Poland. Department of Hydrography and Morphology of River Channels, IMGW, 
Warsaw.

Jankowski AT, Machowski R, Piątek M, et al. (2009) Ice formation characteristics of water bodies in the Upper Silesia Region. In: Marszelewski W (ed.), Anthropogenic and natural transformations of lakes 3. Polish Limnological Society, Toruń, Poland. pp 103-108. (In Polish)

Karetnikov S, Naumenko M (2011) Lake Ladoga ice phenology: mean condition and extremes during the last 65 years. Hydrological Processes 25: 2859-2867.

https://doi.org/10.1002/hyp.8048

Kiełkowski J (2018) Conquering the Tatra Mountains - history and chronicle of climbing in Tatra Mountains. STAPIS Publisher, Katowice. Poland. p 368 (In Polish)

Kiili M, Pulkkanen M, Salonen K (2009) Distribution and development of under-ice phytoplankton in 90-m deep water column of Lake Päijänne (Finland) during spring convection. Aquatic Ecology 43: 707-713.

https://doi.org/10.1007/s10452-009-9262-7

Knoll LB, Sharma S, Denfeld BA, et al. (2019) Consequences of lake and river ice loss on cultural ecosystem services. Limnology and Oceanography Letters 4: 119-131. https://doi.org/10.1002/lol2.10116

Kopáček J, Hardekopf D, Majer M, et al. (2004) Response of alpine lakes and soils to changes in acid deposition: the MAGIC model applied to the Tatra Mountains region, Slovakia-Poland. Journal of Limnology 63: 143-156. https://doi.org/10.4081/jlimnol.2004.143

Lei R, Leppäranta M, Erm A, et al. (2011) Field investigations of apparent optical properties of ice cover in Finnish and Estonian lakes in winter 2009. Estonian Journal of Earth Sciences 60: 50-64. https://doi.org/10.3176/earth.2011.1.05

Leppäranta M (1983) A growth model for black ice, snow ice and snow thickness in subarctic basins. Nordic Hydrology 14: 5970. https://doi.org/10.2166/nh.1983.0006

Leppäranta M, Reinart A, Erm A, et al. (2003) Investigation of ice and water properties and under-ice light fields in fresh and brackish water bodies. Nordic Hydrology 34: 245-266.

https://doi.org/10.2166/nh.2003.0006

Leppäranta M (2009) Modelling the formation and decay of lake ice. In: George $\mathrm{G}$ (ed.), The Impact of Climate Change on European Lakes, Springer, Dordrecht. pp 63-83.

https://doi.org/10.1007/978-90-481-2945-4_5

Leppäranta M (2015) Freezing of lakes and the evolution of their ice cover. Berlin, Springer Verlag, p 301.

https://doi.org/10.1007/978-3-642-29081-7

Likens GE (2019) Unusual sequence of ice cover formation on Mirror Lake, New Hampshire, USA. Inland Waters 9: 1-3. https://doi.org/10.1080/20442041.2019.1629216

Lityński A (1914) About the temperature of Tatra Lakes. Pamiętnik Towarzystwa Tatrzańskiego 35: 69-73. (In Polish)

Lityński A (1917) Tatra lakes and the Cladocera inhabiting them. Report of the Physiographic Commission of the Polish Academy of Arts and Sciences 51: 1-88. (In Polish)

Livingstone DM (1997) Break-up dates of alpine lakes as proxy data for local and regional mean surface air temperatures. Climatic Change 37: 407-439.

https://doi.org/10.1023/A:1005371925924

Lopez LS, Hewitt B A, Sharma S (2019) Reaching a breaking point: how is climate change influencing the timing of ice breakup in lakes across the northern hemisphere? Limnology and Oceanography 64: 2621-2631. https://doi.org/10.1002/lno.11239

Łajczak A (1980) Fluctuations in the water levels of chosen Tatra Lakes. Wszechświat 12: 285-287. (In Polish)

Łajczak A (1982) Fluctuation of temperature of the surface water layer in the Tatra Lakes of various exposure. Czasopismo Geograficzne 53: 29-44. (In Polish)

Łajczak A (1996) Hydrologia. In: Mirka Z (ed.), Nature of Tatra National Park, Tatra National Park, Kraków - Zakopane, Poland. pp 169-196. (In Polish)

Łupikasza E, Szypuła B (2019) Vertical climatic belts in the Tatra Mountains in the light of current climate change.
Theoretical and Applied Climatology136: 249-264

https://doi.org/10.1007/s00704-018-2489-2

Machowski R, Ruman M (2009) Ice phenomena in the Czechowice water body. In: Jankowski AT, Absalon D, Machowski R, Ruman M (eds.), Transformation of the water relationships in changing environment conditions, Sosnowiec, Poland. pp 187-196. (In Polish)

Magnuson JJ, Robertson DM, Benson BJ, et al. (2000) Historical trends in lake and river ice cover in the Northern Hemisphere, Science 289: 1743-1746.

https://doi.org/10.1126/science.289.5485.1743

Marszelewski W, Skowron R (2006) Ice cover as an indicator of winter air temperature changes: case study of the Polish Lowland lakes. Hydrological Sciences Journal 51: 336-349. https://doi.org/10.1623/hysj.51.2.336

McCord SA, Schladow SG, Miller TG (2000) Modeling artificial aeration kinetics in ice covered lakes. Journal of Environmental Engineering-ASCE 126: 21-31. https://doi.org/10.1061/(ASCE)0733-9372(2000)126:1(21)

Mościcki WJ (1996) Winter thermic of water of Tatra lakes. Przyroda Tatrzańskiego Parku Narodowego a człowiek 1, Kraków-Zakopane, Poland. p 155-160. (In Polish)

Ohlendorf C, Bigler C, Goudsmit GH, Lemcke G, Livingstone DM, Lotter RAF, Müller B, Sturm M (2000) Causes and effects of long ice cover on a remote high Alpine Lake. Journal of Limnology 59: $65^{-80}$. https://doi.org/10.4081/jlimnol.2000.s1.65

Olszewski P (1948a) Newer observations on the ice covers of Tatra Lakes. Geografia w Szkole 1: 10-12. (In Polish)

Olszewski P (1948b) Winter oxygen conditions of larger Tatra Lakes. Rozprawy Akademii Umiejętności 72, pp 1-80. (In Polish)

Olszewski P (1949a) The differences of winter stratifications in the Tatra Lakes. Wszechświat 3: 88-91. (In Polish)

Olszewski P (1949b) The physical limnology researches in the Tatra Moutains. Wierchy 19: 218-219. (In Polish)

Olszewski P (1950) The Further limnological researches on the Tatra lakes. Wierchy 20: 236-237. (In Polish)

Olszewski P (1955) Researches in the field of physical limnology in the Tatras. Wierchy 24: 157. (In Polish)

Pacl J, Wit-Jóźwik K (1974) Thermic of water. In: Konček M(ed.), Climate of the Tatra Mountains, Bratislava. pp 181204. (In Slovak)

Pawłowski B (2018) Changes in the course of ice phenomena on Morskie Oko in the Tatra Mountains from 1963 to 2012 and the implications for tourism. Limnological Review 18: 167173. https://doi.org/10.2478/limre-2018-0018

Piątek M, Solarski M, Rzętała M, et al. (2010) Ice phenomena in chosen anthropogenic water reservoirs of Katowice Upland. In: Ciupa T, Suligowski R (eds.), Water in the geographical researches, Kielce, Poland. pp 243-252. (In Polish)

Pociask-Karteczka J, Choiński A (2012) Recent trends in ice cover duration for Lake Morskie Oko (Tatra Mountains, EastCentral Europe). Hydrology Research 43: 500-506. https://doi.org/10.2166/nh.2012.019

Pociask-Karteczka J, Choiński A, Nieckarz Z (2014) Dynamics of water stages. In: Choiński A, PociaskKarteczka J (eds.), Morskie Oko - Nature and Man. Tatra National Park, Zakopane, Poland. (In Polish)

Prowse TD, Stephenson RL (1986) The relationship between winter lake cover, radiation receipts and the oxygen deficit in temperate lakes. Atmosphere-Ocean 24: 386-403. https://doi.org/10.1080/07055900.1986.9649259

Ptak M, Wrzesiński D, Choiński A (2017) Long-term changes in the hydrological regime of high mountain lake Morskie Oko (Tatra Mountains, Central Europe). Journal of Hydrology and Hydromechanics 65: 146-153.

https://doi.org/10.1515/johh-2017-0005

Radwańska-Paryska Z, Paryski WH (1995) The Great Encyclopedia of the Tatras. Moutain Publisher, Poronin, Poland. p 1553. (In Polish)

Rzętała M, Solarski M (2011) Daily field observations as a 
identification source of the water reservoir ice cover new forms and processes. In: Machowski R, Rzętała MA (eds.), Z badań nad wpływem antropopresji na środowisko 12, Sosnowiec, Poland. pp 155-164. (In Polish)

Salonen K, Leppäranta M, Viljanen M, Gulati RD (2009) Perspectives in winter limnology: closing the annual cycle of freezing lakes. Aquatic Ecology 43: 609-616. https://doi.org/10.1007/s10452-009-9278-Z

Santibáñez PA, Michaud AB, Vick-Majors TJ, et al. (2019) Differential Incorporation of Bacteria, Organic Matter, and Inorganic Ions Into Lake Ice During Ice Formation. Journal of Geophysical Research: Biogeosciences 124: 585-600. https://doi.org/10.1029/2018JG004825

Sharma S, Blagrave K, Magnuson JJ, et al. (2019) Widespread loss of lake ice around the Northern Hemisphere in a warming world. Nature Climate Change 9: 227-231. https://doi.org/10.1038/s41558-018-0393-5

Shuter BJ, Finstad AG, Helland IP, et al. (2012) The role of winter phenology in shaping the ecology of freshwater fish and their sensitivities to climate change. Aquatic Sciences 74: 637-657. https://doi.org/10.1007/s00027-012-0274-3

Sokolnikov VN (1969) Ledovy rezhim. Atlas Baikala, GUGK, Irkuck-Moskwa, Russia. p 30. (In Russian)

Solarski M, Pradela A (2010) Course of ice phenomena in the water body in the subsidence depression in winter season 2008/2009. Kształtowanie środowiska geograficznego i ochrona przyrody na obszarach uprzemysłowionych i zurbanizowanych 42: 70-79. (In Polish)

Solarski M, Pradela A, Rzętała M (2011) Natural and anthropgenic infuences on ice formation on various water bodies of the Silesian Upland (Southern Poland). Limnological Review 11: 33-44. https://doi.org/10.2478/v10194-011-0025-1

Solarski M (2017) The ice phenomena dynamics of small anthropogenic water bodies in the Silesian Upland, Poland. Environmental \& Socio-economic Studies 5: 74-81.

https://doi.org/10.1515/environ-2017-0022

Šporka F, Livingstone DM, Stuchlík E, et al. (2006) Water temperatures and ice cover in lakes of the Tatra Mountains. Biologia, Bratislava 61: S77-S90.

https://doi.org/10.2478/s11756-006-0121-x

Szaflarski J (1932) Studies on the thermics of Tatra lakes. Przegląd Geograficzny 12: 181-194. (In Polish)

Szaflarski J (1936a) Thermal regime and freezing of the Zmarzle Stawy in the High Tatra. Bulletin international de l'Académie polonaise des sciences et des lettres, Serie A, Kraków, Poland. pp 510-521. (In French)
Szaflarski J (1936b) Ice phenomena and water thermic of the Zamarzte Stawy in the High Tatra. Reports on Activities and Meetings of the Polish Academy of Arts and Sciences. p 217. (In Polish)

Szaflarski J (1948) The issues of winter thermic of Tatra lakes. Przegląd Geograficzny 20: 281-289. (In Polish)

Świerz L (1893) The temperature relations of the Tatra lakes according to measurements made during the summer season of 1892 in various depths. Pamiętnik Towarzystwa Tatrzańskieg 014: 1-4. (In Polish)

Świerz L (1894) Meteorological records from the Tatras and the temperature of the Tatra lakes. Pamiętnik Towarzystwa Tatrzańskiego 15: 1-11. (In Polish)

Terzhevik AY, Golosov SD, Palshin NI, et al. (2009) Some features of the thermal and dissolved oxygen structure in boreal, shallow ice-covered Lake Vendyurskoe, Russia. Aquatic Ecology 43: 617-627. https://doi.org/10.1007/s10452-009-9288-x

Terzhevik AY, Palshin NI, Golosov SD, et al. (2010) Hydrophysical aspects of oxygen regime formation in a shallow ice-covered lake. Water Resources 37: 662-673. https://doi.org/10.1134/Soo97807810050064

Wierzejski A (1881) About the fauna of the Tatra Lakes. Pamiętnik Towarzystwa Tatrzańskiego 6: 99-110. (In Polish)

Wojkowski J (2015) Solar radiation. In: Atlas of the Tatra Mountains. Abiotic Nature, sheet, II.1, Tatra National Park, Zakopane, Poland.

Wrzesiński D, Choiński A, Ptak M (2016) Effect of North Atlantic Oscillation on the hydrological conditions of Lake Morskie Oko (Carphatian Mountains). Bulletin of Geography. Physical Geography Series 10: 95-105. https://doi.org/10.2478/8734

Wüest A, Pasche N, Ibelings BW, et al. (2019) Life under ice in Lake Onego (Russia) - an interdisciplinary winter limnology study. Inland Waters 9: 125-129.

https://doi.org/10.1080/20442041.2019.1634450

Zhu S, Ptak M, Choiński A, Wu S (2020) Exploring and quantifying the impact of climate change on surface water temperature of a high mountain lake in Central Europe. Environmental Monitoring and Assessment 192. https://doi.org/10.1007/s10661-019-7994-y

Żmudzka E (2011) Contemporary climate changes in the high mountain part of the Tatras. Miscellanea Geographica 15: 93102. https://doi.org/10.2478/v10288-012-0005-6

Žiak M, Długosz M (2015) Potential avalanches. In: Atlas of the Tatra Mountains. Abiotic Nature, sheet, V.3, Tatra National Park, Zakopane, Poland. 